\title{
Botrytis cinerea and Table Grapes: A Review of the Main Physical, Chemical, and Bio-Based Control Treatments in Post-Harvest
}

\author{
Nicola De Simone ${ }^{1}$, Bernardo Pace ${ }^{2}{ }^{\circ}$, Francesco Grieco ${ }^{3}\left(\mathbb{D}\right.$, Michela Chimienti $^{4}$, \\ Viwe Tyibilika $^{5}$, Vincenzo Santoro ${ }^{6}$, Vittorio Capozzi ${ }^{2, *}{ }^{\mathbb{D}}$, Giancarlo Colelli $^{1}$, \\ Giuseppe Spano ${ }^{1}$ and Pasquale Russo ${ }^{1}$ \\ 1 Department of the Sciences of Agriculture, Food and Environment, University of Foggia, Via Napoli 25, \\ 71122 Foggia, Italy; nicola_desimone.552001@unifg.it (N.D.S.); giancarlo.colelli@unifg.it (G.C.); \\ giuseppe.spano@unifg.it (G.S.); pasquale.russo@unifg.it (P.R.) \\ 2 Institute of Sciences of Food Production, National Research Council of Italy (CNR), c/o CS-DAT, \\ Via Michele Protano, 71121 Foggia, Italy; bernardo.pace@ispa.cnr.it \\ 3 Institute of Sciences of Food Production, National Research Council of Italy (CNR), \\ Via Prov.le Lecce-Monteroni, 73100 Lecce, Italy; francesco.grieco@ispa.cnr.it \\ 4 InResLab Scarl, Contrada Baione, 70043 Monopoli, Italy; m.chimienti@inreslab.org \\ 5 AgroSup Dijon, 21079 Dijon CEDEX, France; viwetyibilika@gmail.com \\ 6 A.B.A. Mediterranea s.c.a.r.l., Via Parini, 1, 74013 Ginosa, Italy; enzo.santoro@abamediterranea.it \\ * Correspondence: vittorio.capozzi@ispa.cnr.it; Tel.: +39-0881-630201
}

Received: 23 June 2020; Accepted: 11 August 2020; Published: 19 August 2020

\begin{abstract}
Consumers highly appreciate table grapes for their pleasant sensory attributes and as good sources of nutritional and functional compounds. This explains the rising market and global interest in this product. Along with other fruits and vegetables, table grapes are considerably perishable post-harvest due to the growth of undesired microorganisms. Among the microbial spoilers, Botrytis cinerea represents a model organism because of its degrading potential and the huge economic losses caused by its infection. The present review provides an overview of the recent primary physical, chemical, and biological control treatments adopted against the development of B. cinerea in table grapes to extend shelf life. These treatments preserve product quality and safety. This article also focuses on the compliance of different approaches with organic and sustainable production processes. Tailored approaches include those that rely on controlled atmosphere and the application of edible coating and packaging, as well as microbial-based activities. These strategies, applied alone or in combination, are among the most promising solutions in order to prolong table grape quality during cold storage. In general, the innovative design of applications dealing with hurdle technologies holds great promise for future improvements.
\end{abstract}

Keywords: table grapes; Botrytis cinerea; grey mould; spoilage microbes; post-harvest; modified atmosphere packaging (MAP); ozone $\left(\mathrm{O}_{3}\right)$; antimicrobial compounds; preservatives; biocontrol

\section{Introduction}

Viticulture is one of the major forms of fruit crop cultivation worldwide, and its global diffusion contributes considerably to human nutrition. The fruit has a non-climacteric character with a quite low rate of physiological activity. Grapes (Vitis vinifera L.) are essential not only for wine production but also for fresh consumption. Table grapes are highly appreciated by consumers, primarily because of their sensory attributes, but also because of their vitamins and bioactive compounds (e.g., flavonoids) [1]. More than 27 million tons of table grapes are produced worldwide annually 
(an increase of $71 \%$ since 2000), and about 4.2 million tons were exported among countries in 2014 [2]. Accordingly, increasing attention has been paid to lengthening the shelf-life of table grapes for export. Prolonged storage time preserves marketability and adds value; however, it is often associated with a decrease in overall product quality. In general, several factors, including bunch dehydration, rachis browning, peel colour changes, lacerations and colonization by various spoilage fungi result in significant economic losses.

Among other factors, fungal decay represents the principal factor responsible for post-harvest deterioration in table grapes [3]. Botrytis cinerea is the main biological cause of post-harvest problems since it is accountable for grey mould formation [4]. Indeed, this undesired fungus is ranked second in the "world top 10 fungal pathogens in molecular plant pathology" in terms of economic and scientific relevance, preceded only by Magnaporthe oryzae [5]. Fungal spores are generally present on the surface of fruits, and, during post-harvest handling the berries can supply a suitable environment for spore germination (mainly the damaged fruits) (Figure 1).

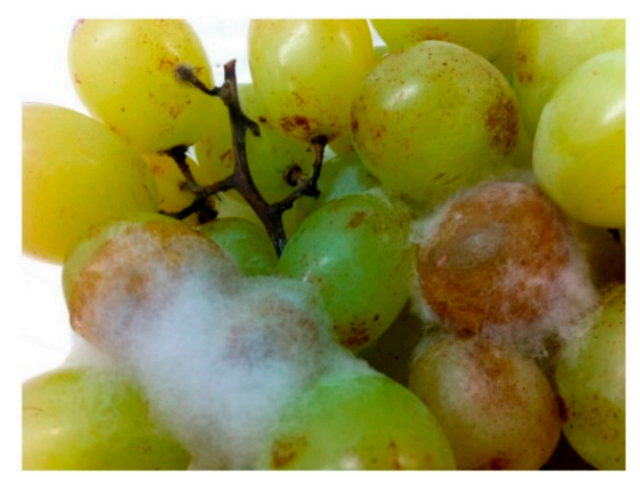

Figure 1. Effect of grey mould on cold-stored cv. "Italia" table grape berries. Image from Ahmed et al. [3].

Moreover, the infection can occur during storage, marketing, and even after customer purchase. In the vineyard, high relative air humidity and low environmental temperatures reduce the host's defences. This environment favours the rapid spread of contamination from a single berry to the whole bunch [6,7]. During post-harvest treatments of fruits and vegetables, processing technologies and biotechnologies provide physical, chemical, and biological hurdles to limit the development of undesired microorganisms [8]. Changes in technical and technological solutions, consumer needs, and regulatory framework lead to a continuous evolution of the handling procedures to limit decay induced by spoilage fungi. All of these advances are generally tailored to reducing and averting spoilage growth, but they are more broadly oriented towards optimization of global quality of production, including safety, health properties, and sensory acceptability [9-12].

Among the economic and social trends, attention to sustainable viticulture and organic production represents a field of high interest, as evidenced by the rising number of cultivated hectares worldwide (Figure 2).

Nowadays, this kind of table grape cultivation is still increasing in diffusion and economic importance [13]. The production of organic grapes necessitates compliance with specific regulations that limit the chemicals allowed during production and distribution [14]. In general, organic-labelled products are defined as those from plantations that respect and exploit biodiversity, organic turnovers, and soil structure [14]. The European Union has led the cultivation of organic grapes globally, followed by China, the United States of America, and Turkey [15]. Within Europe, the countries with the most extensive acreages dedicated to organic farming are Spain and Italy (1.9 and 1.4 million hectares, respectively; both contributing more than 100,000 hectares to the increase in organic land observed in Europe) [15].

In recent years, different strategies have been proposed to control B. cinerea in order to improve the management of post-harvest decay in table grapes and to prevent quality losses [16-18]. The present 
review aims to discuss the more recent investigations conceived to control B. cinerea decay in table grapes, including the primary physical, chemical, and biological approaches.

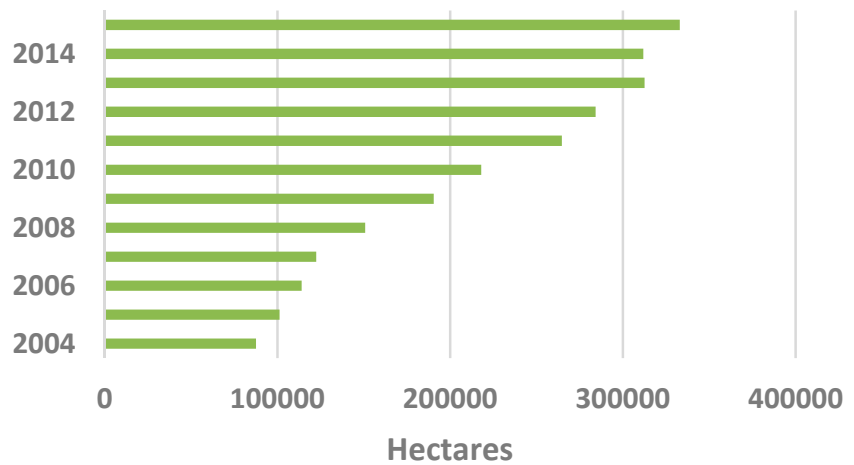

Figure 2. Global area for the cultivation of organic grapes in the period 2004-2015. Source: Research Institute of Organic Agriculture (FiBL) and IFOAM-Organics International-SOEL magazine (2006-2017).

\section{Physical Methods to Control B. cinerea in Table Grapes}

Physical technologies mainly include modification of several parameters such as temperature, absolute and relative gas pressure, UV irradiation, and sonication. Table grapes for fresh consumption often need a long period of storage for commercial purposes such as export and ready-to-eat. They are usually stored in chambers with strictly controlled temperature and humidity. To this aim, cold storage $\left(\sim 0^{\circ} \mathrm{C}\right)$ is the primary method to avoid post-harvest infections without affecting the main physicochemical features of the product [19]. However, B. cinerea survives at low temperatures, and any variation of temperature can promote water condensation, thus favouring fungal growth and sporulation [20]. In general, physical methods are often considered eco-friendly and residue-free emerging technologies, widely accepted by consumers. Although these methods have been extensively investigated in different fruit and vegetable products, only a few studies report their employment for the reduction of grey mould in table grapes (Table 1).

Surface sanitation is the main strategy implemented to control microbial contamination of fruits and it can be achieved by using different methods. Among these, dipping in hot water (about $50{ }^{\circ} \mathrm{C}$ ) is an interesting option to prolong the shelf-life of fruits and vegetables [33,34]. Treatments at $50{ }^{\circ} \mathrm{C}$ for $10 \mathrm{~min}$, or at $55^{\circ} \mathrm{C}$ for $5 \mathrm{~min}$, are sufficient to reduce the fungal growth, maintaining product quality because it does not alter the grape's organoleptic profile $[21,22]$. Accordingly, it allows for the marketability of minimally-processed and ready-to-eat table grapes [21,22]. Nonetheless, more studies are requested to improve the processing conditions, i.e., temperature and time of exposure against B. cinerea contamination. 
Table 1. Main physical methods investigated in the last ten years against grey mould decay in table grapes.

\begin{tabular}{|c|c|c|c|c|}
\hline Physical Methods & Treatment Intensity & Cultivar & Effects & Ref. \\
\hline \multirow{2}{*}{ Hot Water Treatments } & Dipping for $5 \mathrm{~min}$ at $55^{\circ} \mathrm{C}$ & Müşküle and Red Globe & $\begin{array}{l}\text { Low decay rate after three weeks of cold storage; sensory evaluation } \\
\text { results showed no alteration of flavor and taste }\end{array}$ & {$[21]$} \\
\hline & Dipping for $10 \mathrm{~min}$ at $50^{\circ} \mathrm{C}$ & Crimson Seedless & $\begin{array}{l}\text { Inhibition the microbial growth during storage without significant } \\
\text { changes in texture, titratable acidity, and soluble solids content }\end{array}$ & [22] \\
\hline Ultrasound & $32 \mathrm{kHz}$ at $20^{\circ} \mathrm{C}$ for $10 \mathrm{~min}$ & Michele Palieri & $\begin{array}{l}\text { Combined with putrescine, the treatment maintained high levels of } \\
\text { anthocyanins, total phenolic content, antioxidant capacity, sensory } \\
\text { acceptability and reduced decay incidence during storage }\end{array}$ & [23] \\
\hline UV-C Irradiation & $\begin{array}{l}\text { Two times at } 6.0 \mathrm{~kJ} / \mathrm{m}^{2} \text { for } 1 \mathrm{~min} \\
\text { at } 60 \mathrm{~cm}\end{array}$ & Crimson & $\begin{array}{l}\text { Combined with chitosan coating, the treatment increased the resveratrol } \\
\text { content, maintained sensorial quality, and reduced fungal decay }\end{array}$ & [24] \\
\hline High Pressure & $0.15 \mathrm{MPa}$ for $24 \mathrm{~h}$ at $20^{\circ} \mathrm{C}$ & Italia & Reduction of lesion diameter and decay rate after three days of shelf-life & [25] \\
\hline $\begin{array}{l}\text { Electrolyzed oxidizing } \\
\text { water }\end{array}$ & $\begin{array}{l}(250 \mathrm{ppm} \text { TRC; } \mathrm{pH}=6.3-6.5 \\
\mathrm{ORP}=800-900 \mathrm{mV}, 1 \% \mathrm{NaCl}) \\
\quad \text { dipping and daily spray }\end{array}$ & Thompson seedless & $\begin{array}{l}\text { Prevention of infection until seven days; } 1 \% \text { of incidence and } 2 \% \text { of } \\
\text { severity were reported after } 10 \text { days of shelf-life at } 25{ }^{\circ} \mathrm{C}\end{array}$ & [26] \\
\hline \multirow{3}{*}{ CA } & $12 \% \mathrm{O}_{2}+12 \% \mathrm{CO}_{2}$ & $\begin{array}{l}\text { Flame Seedless and } \\
\text { Crimson Seedless }\end{array}$ & $\begin{array}{l}\text { Combined with } \mathrm{CO}_{2} \text {, the treatment limited decay incidence in both } \\
\text { naturally and artificially infected grapes }\end{array}$ & [27] \\
\hline & $0.3 \mu \mathrm{L} / \mathrm{L} \mathrm{O}_{3}$ & Sultanina & $\begin{array}{l}\text { Reduction of fungal decay during } 40 \text { days of cold storage; no significant } \\
\text { alteration of quality characteristics }\end{array}$ & {$[28]$} \\
\hline & $0.1-0.3 \mu \mathrm{L} / \mathrm{L} \mathrm{O}_{3}$ & Crimson Seedless & $\begin{array}{l}\text { Reduction of natural incidence of decay by approximately } 65 \% \text { after } \\
\text { five-eight weeks of storage. }\end{array}$ & [29] \\
\hline \multirow{3}{*}{ MAP } & $\begin{array}{l}\text { Passive modifications } \\
\text { packaging-induced }\end{array}$ & Vittoria and Red Globe & Reduction of weight losses, rachis and berry decay & {$[30]$} \\
\hline & $2 \% \mathrm{O}_{2}+5 \% \mathrm{CO}_{2}$ & Scarlotta & $\begin{array}{l}\text { Combined with } \mathrm{O}_{3} \text {, the treatment was efficient in decay control but } \\
\text { caused sensorial quality losses (intense stem browning, } \\
\text { off-flavors perception) } \\
\text { Combined with } \mathrm{CO}_{2} \text {, the treatment controlled the concentration of } \\
\text { acetaldehyde, preserved rachis chlorophyll content and skin color; } \\
\text { also, cumulative decay incidence was reduced }\end{array}$ & {$[31]$} \\
\hline & Initial concentration of $10 \% \mathrm{CO}_{2}$ & Italia & $\begin{array}{c}\text { Decay control during } 14 \text { days of cold storage, and three days of shelf life, } \\
\text { low acetaldehyde, and ethanol accumulation }\end{array}$ & {$[32]$} \\
\hline
\end{tabular}


Ultraviolet irradiation (UV) (wavelengths between 10 to 400 nanometers (nm)) and sonication by ultrasound are non-thermal treatments considered simple, reliable, and eco-friendly emerging technologies for lengthening the shelf life of fresh fruits during storage. Ultraviolet irradiation C (UV-C, 10-280 nm) treatment induced a general stimulation of the phenylpropanoid pathway, associated with plant defence mechanisms, leading to an increased resistance to the diseases in artificially inoculated berries [24]. UV-C irradiation is effective, with dosages between 0.125 to $0.5 \mathrm{~kJ} / \mathrm{m}^{2}$ at a fixed distance of $25 \mathrm{~cm}$ [35]. In a recent study, harvested 'Crimson' red table grapes were exposed to an increased UV-C intensity $\left(6.0 \mathrm{~kJ} / \mathrm{m}^{2}\right)$, for two illumination periods of $1 \mathrm{~min}$ with a specific distance of $60 \mathrm{~cm}$ and then maintained at $20^{\circ} \mathrm{C}$ for $24 \mathrm{~h}$, followed by cold storage [24]. Regarding ultrasound application, Bal et al. [23] demonstrated the effectiveness of this treatment at $32 \mathrm{kHz}$, in a distilled water chamber at $20{ }^{\circ} \mathrm{C}$ for $10 \mathrm{~min}$. Their study produced encouraging results in preserving grape quality throughout storage for 60 days. A reduction of decay rate was shown and evaluated by scoring the number of contaminated berries, from 2.8 (water-treated control) to 1.5 (ultrasound treated grapes), in an acceptability scale from 1 to 5 points $(1=$ no decay; $5=$ over 20 decayed berries per bunch in a box of $5 \mathrm{~kg}$ grapes). It is essential to underline that, in the last two studies, both UV irradiation and sonication are also compared to treatments which combine physical methods with biological compounds, such as chitosan (an antimicrobial linear polysaccharide derived from chitin) and putrescine (biogenic diamine, a class of compound with relevant biological properties), respectively.

Few studies are reported on the use of high hydrostatic pressure and electrolyzed oxidizing water (EOW), especially on table grapes. Romanazzi et al. [25] investigated the efficiency of hyperbaric treatments at $0.15 \mathrm{MPa}$ for $24 \mathrm{~h}$, on artificially inoculated 'Italia' table grapes berries, during simulated shelf-life for three days at $20^{\circ} \mathrm{C}$. A significant reduction of the infected berries (from 49.0 to $30.8 \%$ ) and of their lesion diameter (from 8.7 to $7.2 \mathrm{~mm}$ ) was reported for the treated grapes, when compared to control fruits stored at ambient pressure [25]. Electrolyzed oxidizing water is produced through the controlled electrolysis of sodium chloride solutions. Dipping in EOW [250 ppm total residual chlorine (TRC); $\mathrm{pH}=6.3-6.5 ; \mathrm{ORP}=800-900 \mathrm{mV}, 1 \% \mathrm{NaCl}$ ] was adequate to prevent the infection of green table grapes artificially contaminated with $B$. cinerea until one week, showing a decay rate of $2 \%$ after ten days of storage at $25{ }^{\circ} \mathrm{C}$ [26]. Interestingly, a dipping treatment followed by a daily spray of grapes with EOW prevented the infection until 24 days, showing a daily decay rate of $2 \%$ after 26 days of storage at $25^{\circ} \mathrm{C}$ [26].

The modification of absolute and relative gas pressure, in association with low temperatures during storage, is an important strategy to enhance the shelf life of fruits and vegetables [36]. The main methods include controlled atmosphere (CA) and modified atmosphere packaging (MAP). $\mathrm{CA}$ is defined as an atmosphere different than air, applied to commodities in the storage chamber. MAP involves a change in gas environment in packaged commodities, as a result of respiration (passive MAP) or by the different gas permeability of the packaging (active MAP) [37]. The latter method has received considerable attention because of the possibility of maintaining modifications up to consumption [38-40]. In both CA and MAP approaches, the use of different gas composition (e.g., changes in ratio Oxygen $\left(\mathrm{O}_{2}\right)$ /Carbon dioxide $\left(\mathrm{CO}_{2}\right)$ ) aims to minimize the metabolic activity and oxidative phenomena, thus reducing the physiological decay caused by aerobic microorganisms (e.g., B. cinerea) [36,39]. In table grapes, an atmosphere with different gas composition, including high $\mathrm{CO}_{2} /$ low $\mathrm{O}_{2}$ concentrations [41-43], and the addition of $\mathrm{O}_{3}$ [42], has the effect of reducing decay. Furthermore, this strategy retards senescence, reduces stem and berry respiration, limits rachis browning, and preserves berry firmness [41-43]. However, $\mathrm{CO}_{2}$ concentrations $>10 \%$ reportedly promote off-flavor development, rachis and berries' browning [43]. CA with ozone $\left(\mathrm{O}_{3}\right)$ at $0.3 \mu \mathrm{L} / \mathrm{L}$ was assessed as the minimum concentration to significantly inhibit decay development, in artificially contaminated berries, up to seven weeks in cold storage [28,44]. Recently, in similar storage conditions, ozone-CA with $0.1 \mu \mathrm{L} / \mathrm{L}$ in the day and $0.3 \mu \mathrm{L} / \mathrm{L}$ at night, was found to effectively reduce grey mould, even after 68 days, with a maximum disease incidence of $2.1 \%$, comparable to weekly $\mathrm{SO}_{2}$-fumigated grapes [29]. Passive MAP in micro-perforated polypropylene films, was found to have the highest 
performance in the decay management of 'Vittoria' and 'Red Globe' table grapes [30]. Cefola and Pace [32] reported best results on 'Italia' table grapes, after 14 days of cold storage and three days of shelf-life, by using MAP with an initial concentration of $10 \% \mathrm{CO}_{2}$, both in terms of sensory quality preservation and decay control. Considering that the use of massive doses of gas in a single pre-storage application can be defined as a sanitation procedure, we refer the discussion to chemical methods following section.

\section{Chemical Methods to Control B. cinerea in Table Grapes}

At present, sulphur dioxide $\left(\mathrm{SO}_{2}\right)$ remains the main method that is used to control the microbial spoilage of post-harvest fruit commodities. The employment of $\mathrm{SO}_{2}$ provides long term storage due to its antioxidant, antibacterial, antifungal and anti-browning properties [19,45]. However, excessive residue levels of $\mathrm{SO}_{2}$ in berry peels can result in quality deterioration, such as bleached berries, production of off-flavour, or hairline disorder [46,47]. Significant health risks to consumers are also reported due to the emergence of allergies, nausea, respiratory distress and skin rashes [48]. For this reason, the United States Environmental Protection Agency (USEPA) categorized $\mathrm{SO}_{2}$ as a pesticide, with maximum tolerance in final products of $10 \mathrm{ppm}$, and, more generally, sulphur dioxide residuals on table grapes are internationally regulated, including in the European Union [49,50]. Its use is also excluded from certified "organic" grapes [16]. Therefore, several chemical alternatives have been proposed to replace $\mathrm{SO}_{2}$ in the restraint of $B$. cinerea in table grapes (Table 2).

The use of conventional synthetic fungicides is generating increasing concern among consumers due to the potential negative effects on human health [61], soil microbiota [62], and on microorganisms beneficial for food and beverage fermentations [63]. Even if the use of conventional synthetic fungicides is forbidden for organic grapes [14], application is widespread to prevent spoilage mould formation in conventional agriculture [64]. Despite the fact that some studies have focused on the positive action of different combinations of synthetic fungicides or bioactive compounds [51], the occurrence of resistant strains of $B$. cinerea has been reported [65]. The most recently introduced class of synthetic fungicides belongs to the Succinate Dehydrogenase Inhibitors (SDHIs) [66]. In 2012, a novel SDHI, named fluopyram, was registered against $B$. cinerea and it was able to control grey mould infections in table grapes, with efficacy of inhibition in the range 80.1-94.4\% [52]. However, high risks of rapid occurrence of resistance without appropriate management has already been underlined in other crops [67]. For this reason, alternative control methods are needed. Among these, resistance induced by elicitors, molecules able to activate defence gene expression and enhance their antimicrobial-related pathways [68], is an attractive alternative because it is associated with minor environmental risk. Acibenzolar-S-methyl is a commercial elicitor able to activate the phenylpropanoid pathway, which leads to the accumulation of lignin, phenolic compounds and flavonoids [68]. In table grapes, it can be used as spray aspersion or dipping solution, both with a significant reduction in terms of decay incidence [53]. 
Table 2. Main chemical methods investigated in the last ten years against grey mould decay in table grapes.

\begin{tabular}{|c|c|c|c|c|c|c|}
\hline & Molecules & Treatment & Concentration & Cultivar & Effects & Ref. \\
\hline \multirow{5}{*}{ Liquid } & Pyrimethanil & Wound inoculation & $50 \mathrm{mg} / \mathrm{L}$ & Crimson Seedless & $\begin{array}{l}\text { Combined with resveratrol }(1 \mathrm{~g} / \mathrm{L}) \text {, the treatment reduced } \\
\text { disease incidence and lesion diameter }\end{array}$ & [51] \\
\hline & Fluopyram & Spraying & $250 \mu \mathrm{g} / \mathrm{mL}$ & Italia & Efficacy against fungicide-resistant fungal strains & [52] \\
\hline & Acibenzolar-S-methyl & Dipping & $1 \% \mathrm{w} / \mathrm{v}$ & Italia and Benitaka & $\begin{array}{l}\text { Reduction of grey mould development after one month } \\
\text { of cold storage and one week of shelf life, } \\
\text { without alteration of the physicochemical quality }\end{array}$ & [53] \\
\hline & Ethanol & Dipping & $32 \%$ & Scarlotta Seedless & Reduction of berries decay until ten weeks of storage & [54] \\
\hline & $\begin{array}{l}\mathrm{FeSO}_{4}, \mathrm{NH}_{4} \mathrm{HCO}_{3} \\
\mathrm{Na}_{2} \mathrm{SiO}_{3}, \mathrm{NaHCO}_{3} \\
\quad \text { and } \mathrm{Na}_{2} \mathrm{CO}_{3}\end{array}$ & Dipping or spraying & $1 \% \mathrm{w} / \mathrm{v}$ & Benitaka & $\begin{array}{l}\text { Decay incidence reduced, no impact on berries quality } \\
\text { parameters with minor exceptions which were at an } \\
\text { acceptable level }\end{array}$ & [55] \\
\hline \multirow{8}{*}{ Gas } & Ethanol & $\begin{array}{l}\text { Vapour-generating } \\
\text { bags }\end{array}$ & - & Red Globe & $\begin{array}{l}\text { Comparable to } \mathrm{SO}_{2} \text { treatments in decay control, } \\
\text { the treatment enhanced berry colour, but caused } \\
\text { stem browning }\end{array}$ & [56] \\
\hline & $\begin{array}{l}\text { Chlorine dioxide } \\
\qquad\left(\mathrm{ClO}_{2}\right)\end{array}$ & Injection in bag & $2.5 \mathrm{mg} / 5 \mathrm{~kg}$ & Kyoho & Reduction of berry decay and rachis browning & [57] \\
\hline & $\begin{array}{l}\text { Nitrous oxide } \\
\qquad\left(\mathrm{N}_{2} \mathrm{O}\right)\end{array}$ & Fumigation & $50 \mu \mathrm{L} / \mathrm{L}$ & Munage & Reduction of lesion diameter and decay incidence & [58] \\
\hline & \multirow{3}{*}{$\begin{array}{l}\text { Carbon dioxide } \\
\qquad\left(\mathrm{CO}_{2}\right)\end{array}$} & Fumigation & $20 \%$ & Cardinal & $\begin{array}{l}\text { The treatment avoided post-harvest losses in terms of } \\
\text { water loss, oxidative damage and disease prevention }\end{array}$ & [59] \\
\hline & & Fumigation & $40 \%$ & $\begin{array}{l}\text { Flame Seedless and } \\
\text { Crimson Seedless }\end{array}$ & $\begin{array}{l}\text { Combined with CA, the treatment limited decay } \\
\text { incidence in both naturally and artificially infected grapes }\end{array}$ & [27] \\
\hline & & Fumigation & $50-70 \%$ & Scarlotta & $\begin{array}{l}\text { Combined with MAP }\left(2 \% \mathrm{O}_{2}+5 \% \mathrm{CO}_{2}\right) \text {, the treatment } \\
\text { was efficient in decay control but caused sensorial quality } \\
\text { losses (intense stem browning, off-flavours perception) }\end{array}$ & [31] \\
\hline & \multirow[t]{2}{*}{ Ozone $\left(\mathrm{O}_{3}\right)$} & Fumigation & $20 \mu \mathrm{L} / \mathrm{L}$ & Scarlotta & $\begin{array}{l}\text { Combined with MAP }\left(2 \% \mathrm{O}_{2}+5 \% \mathrm{CO}_{2}\right) \text {, the treatment } \\
\text { controlled the concentration of acetaldehyde, preserved } \\
\text { rachis chlorophyll content and skin colour; } \\
\text { the cumulative decay incidence was also reduced }\end{array}$ & [31] \\
\hline & & Periodic fumigation & $2 \mu \mathrm{L} / \mathrm{L}$ & $\begin{array}{l}\text { Superior Seedless, } \\
\text { Cardinal CL80, } \\
\text { and Regina Victoria }\end{array}$ & $\begin{array}{l}\text { The treatment increased resveratrol content but led to } \\
\text { low scores in sensory evaluation; high weight loss was } \\
\text { also reported }\end{array}$ & {$[60]$} \\
\hline
\end{tabular}


Other chemicals are widely used as dipping solutions to sanitize fruit surfaces. The treatment of grapes by immersion or spraying with solutions of different generally recognized as safe (GRAS) salts at $1 \%$ reduced the percentage of spoiled fruit. This was the case with iron sulphate $\left(\mathrm{FeSO}_{4}\right)(92 \%)$, ammonium bicarbonate $\left(\mathrm{NH}_{4} \mathrm{HCO}_{3}\right)(91 \%)$, sodium silicate $\left(\mathrm{Na}_{2} \mathrm{SiO}_{3}\right)(89 \%)$, sodium bicarbonate $\left(\mathrm{NaHCO}_{3}\right)(76 \%)$ and sodium carbonate $\left(\mathrm{Na}_{2} \mathrm{CO}_{3}\right)(74 \%)$ (application in pre-harvest, decay measured post-harvest) [55]. However, treatment with $\mathrm{FeSO}_{4}$ could cause small black spots on the grape surface [55]. Disinfection by dipping in 32\% ethanol, followed by six weeks of cold storage, reduced natural decay incidence on 'Scarlotta Seedless' from about $60 \%$ to $4.1 \%$ [54]. Nevertheless, the use of large quantities of ethanol is expensive and may be dangerous, due to its flammability. A more practical method is the use of ethanol vapour-generating bags, that confer longer protection, effectively reducing decay incidence in artificially inoculated grapes stored for one month, in a comparable way to $\mathrm{SO}_{2}$ generating-pads in polyethylene bags [56]. In this case, significantly lower weight loss and moderate stem browning were also observed [56]. Furthermore, it is relevant to underline that active coatings associated with selected films represent a promising strategy to increase table grape shelf life [69].

Recently, Gorrasi et al. [70] demonstrated the efficacy of active packaging based on a food grade acrylic resin filled with Layered Double Hydroxide (LDH) nanofiller hosting antimicrobial 2-acetoxybenzoic anion (salicylate), on microbial control during table grape (cv Egnathia) storage.

In addition to ethanol vapours, other gas types have been used as fumigation treatment for the sanitization of bunches. With this scope, chlorine dioxide $\left(\mathrm{ClO}_{2}\right)$ is a gaseous disinfectant admitted in the sanitization of uncut and unpeeled fruits and vegetables. In a recent study, Chen et al. [57] reported a reduction of decay incidence and of rachis browning in table grapes treated with $\mathrm{ClO}_{2}$ during storage. The Food and Drug Administration (FDA) has approved $\mathrm{ClO}_{2}$, given that these treatments might leave chlorite residues on food products at non-hazardous concentrations [71]. Nitrous oxide $\left(\mathrm{N}_{2} \mathrm{O}\right)$ is another gas tested to control post-harvest decay in fruit crops. In vitro tests did not show inhibition against grey mould; however, in vivo experiments in table grapes fumigated for $6 \mathrm{~h}$ showed a significant reduction in decay development during six days of cold storage [58]. Therefore, it was hypothesized that $\mathrm{N}_{2} \mathrm{O}$ was indirectly able to inhibit grey mould by increasing the host's disease resistance [58].

The use of pre-treatments with high concentrations of $\mathrm{CO}_{2}$ have been widely studied; these showed great potential in decay control and prevention of water loss and oxidative damage [59]. In Cardinal table grapes, these effects seem to be related to the specific induction of defence proteins, including dehydrins and proteins associated with pathogenesis, as well as endogenous protective osmolytes [59]. In the last few years, different concentrations of $\mathrm{CO}_{2}$ were evaluated. Pre-treatments with $20 \%$ of $\mathrm{CO}_{2}$ for three days [59], $40 \% \mathrm{CO}_{2}$ for $48 \mathrm{~h}$ followed by CA storage [27], and $50-70 \%$ for $24 \mathrm{~h}$ followed by MAP [31], were all effective against post-harvest decay of the cultivars assayed. Although all the treatments guaranteed basic quality standards for commercial table grapes, a concentration-dependent effect has been observed. However, as previously mentioned, the use of pre-storage application of a high concentration of $\mathrm{CO}_{2}$ causes cultivar-dependent collateral effects such as rachis, berries browning and off-flavours [43].

Ozone fumigation is one of the most prominent sanitation strategies for fruits and vegetables $[72,73]$. Different approaches have been developed for ozone-based treatments on table grapes $[74,75]$. Among these, continuous exposure in controlled atmosphere during cold storage has been reported $[28,29]$. Decay reduction was confirmed only with pre-treatment at $20 \mu \mathrm{L} / \mathrm{L}$ for $30 \mathrm{~min}$, followed by MAP storage [31]. Interestingly, intermittent ozone treatment $(2 \mu \mathrm{L} / \mathrm{L}, 12 \mathrm{~h}$ for day) induced higher resveratrol accumulation (in three different table grape cultivars) [60]. Moreover, this could be responsible for decreases in the level of pesticide residues (phenomena reported for grapes stored in ozone atmosphere) [75,76]. Nevertheless, ozone is corrosive and represents a worker hazard [77], and, among the quality parameters, significant weight loss during storage was usually highlighted $[28,44,60]$. 


\section{Biological Methods to Control B. cinerea in Table Grapes}

Consumers widely accept the development of bio-based applications to exert microbial control in agro-food chains because of the growing demand for eco-friendly approaches and products free of synthetic chemicals [78-80]. For these purposes, several protective cultures [81-84] and compounds of biological origin $[80,85]$ have been assessed for their possible use as Biological Control Agents (BCAs) against $B$. cinerea in table grapes.

\subsection{Microbial Resources}

Several yeast species are found in association with the surface of the grapes, in particular, the genera Saccharomyces, Candida, Dekkera, Pichia, Hanseniaspora, Metschnikowia, Kluyveromyces, Saccharomycodes, Schizosaccharomyces, Torulaspora, and Zygosaccharomyces [86,87]. Highly variable in terms of relative proportion, often as a function of the sanitary condition of the grapes, these species have different significances in oenology, i.e., pro-technological, spoilage, biocontrol, production of toxic catabolites [88-92]. On the other hand, it is possible to find prokaryotic organisms present on the grape surface that exert their biotechnological action in the last phases of the winemaking process [93]. This broad microbial diversity justifies massive isolation of yeasts and bacteria to preserve and characterize strains of biotechnological interest [94-96]. This isolation can be of microorganisms from plants, grape bunches, musts or wines and selection is made of those capable of inhibiting undesired microbe development on grapevines $[97,98]$ up to the final steps of wine production [99]. This reservoir of microbial-based biocontrol solutions has also been exploited in fruits [100-103], in several cases offering the option to inhibit B. cinerea in table grapes (Table 3).

Among yeast species, strains belonging to Saccharomyces are the most commonly studied because of their pivotal function in alcoholic fermentation and their role as a biological model organism [117-119]. Recently, Nally et al. [108] used a fruit decay test on wounded table grape berries to screen the activity of 65 yeasts, previously tested against $B$. cinerea by using in vitro approaches. They found that 15 S. cerevisiae strains and one strain of Sch. pombe, isolated from grape must, were able to reduce grey mould decay [108]. Among these, the disease incidence of grapes treated with Sch. pombe BSchp67 reached $29.9 \%$, while 9 strains of S. cerevisiae were able to fully inhibit decay development when added at a concentration of $10^{7}$ cells $/ \mathrm{mL}$ [108].

Regarding the non-Saccharomyces yeasts, H. uvarum is a species of enological interest, usually present on the grape surface $[120,121]$. In various studies, it has demonstrated an antagonistic property, mainly based on competition for living space [122]. The addition of this yeast has been implicated in the reduced incidence of grey mould disease in artificially inoculated table grapes [111]. Moreover, this antagonistic activity was enhanced by the addition in the formulation of salicylic acid or salts, such as sodium bicarbonate or ammonium molybdate [109,123]. Starmerella bacillaris (synonym Candida zemplinina) is another species of interest, commonly isolated from grapevines/musts [124,125] and from wines fermented by using botrytized grapes [126,127]. Three Starm. bacillaris strains, recently isolated from these wines, denoted a significative antifungal activity, probably addressable to the release of volatile organic compounds (VOCs) [110]. The production of VOCs is widely diffused among yeasts. Mewa-Ngongang et al. [112] observed a fungicidal effect of C. pyralidae Y1117 and P. kluyveri Y1125, mediated by VOC release in a closed environment, able to inhibit fungal growth for five weeks of storage [112]. 
Table 3. Main microbial strains investigated in the last ten years against grey mould decay in table grapes. Where possible, Inhibition Percentage (IP), Disease Incidence (DI), and Disease Reduction (DR) were reported to quantify the activity of each strain.

\begin{tabular}{|c|c|c|c|c|c|}
\hline & Microbial Strain & Source of Isolation & Activity & Cultivar Tested & Ref. \\
\hline \multirow{14}{*}{ Yeasts } & Issatchenkia terricola $156 \mathrm{a} 5$ & Thompson seedless & $\mathrm{IP}=\sim 80 \%$ & Flame seedless & [104] \\
\hline & Wickerhamomyces anomalus BS91 & & $\mathrm{DI}=\sim 50 \%$ & \multirow{3}{*}{ Not specified } & \multirow{3}{*}[105,106]{} \\
\hline & Metschnikowia pulcherrima MPR3 & Fermented olive and pomegranate & $\mathrm{DI}=6.7 \%$ & & \\
\hline & Aureobasidium pullulans PI1 & & $\mathrm{DI}=\sim 55 \%$ & & \\
\hline & Meyerozyma guilliermondii Ka21, Kh59 & \multirow{2}{*}{ Thompson seedless } & $\mathrm{IP}=47.6 \%$ & \multirow{2}{*}{ Thompson seedless } & \multirow{2}{*}{ [107] } \\
\hline & Candida membranifaciens Kh69 & & $\mathrm{IP}=\sim 42 \%$ & & \\
\hline & Saccharomyces cerevisiae spp. (9 strains) & \multirow{2}{*}{ Grape must } & $\mathrm{DI}=0 \%$ & \multirow{2}{*}{ Red globe } & \multirow{2}{*}{ [108] } \\
\hline & Schizosaccharomyces pombe BSchp67 & & $\mathrm{DI}=29.92 \%$ & & \\
\hline & Hanseniaspora uvarum SEHMA61 & \multirow{2}{*}{ Wild grape } & - & \multirow{2}{*}{ Not specified } & \multirow{2}{*}{ [109] } \\
\hline & Pichia kluyveri SEHMA6B & & - & & \\
\hline & Starmerella bacillaris PAS151 & Ripe grape must & $\mathrm{DR}=\sim 40 \%$ & \multirow{2}{*}{$\begin{array}{l}\text { Not specified } \\
\text { Kyoho }\end{array}$} & \multirow{2}{*}{$\begin{array}{l}{[110]} \\
{[111]}\end{array}$} \\
\hline & Hanseniaspora uvarum & Strawberry & $\mathrm{DI}=51,8 \%$ & & \\
\hline & Candida pyralidae Y1117 & Grape must & $\mathrm{DI}=0 \%$ & \multirow{2}{*}{ Regal seedless } & \multirow{2}{*}[112,113]{} \\
\hline & Pichia kluyveri Y1125 & Sclerocarya birrea juice & $\mathrm{DI}=0 \%$ & & \\
\hline \multirow{7}{*}{ Bacteria } & $\begin{array}{l}\text { Bacillus sp. Kh26 } \\
\text { Ralstonia sp. N1 }\end{array}$ & Thompson seedless & $\begin{array}{l}\mathrm{IP}=49.9 \% \\
\mathrm{IP}=54.7 \%\end{array}$ & Thompson seedless & [107] \\
\hline & Bacillus amyloliquefaciens NCPSJ7 & Ginger field & $\mathrm{DI}=36 \%$ & \multirow{2}{*}{ Red globe } & \multirow[t]{2}{*}{ [114] } \\
\hline & Bacillus amyloliquefaciens RS-25 & Jujube fruit & $\mathrm{DR}=86.6 \%$ & & \\
\hline & Bacillus licheniformis MG-4 & Strawberry & $\mathrm{DR}=84.7 \%$ & \multirow{3}{*}{ Red globe } & \multirow{3}{*}{ [115] } \\
\hline & Bacillus subtilis Pnf- 4 & Wheat plant & $\mathrm{DR}=69.95 \%$ & & \\
\hline & Bacillus subtilis Z-14 & Wheat soil & $\mathrm{DR}=42.43 \%$ & & \\
\hline & Paenibacillus pasadenensis R16 & Barbera & $\mathrm{DR}=27.5 \%$ & Black magic & [116] \\
\hline
\end{tabular}


In vivo studies demonstrated that grey mould can be efficiently controlled by various microbial antagonists isolated from a large variety of vegetal matrices. Wickerhamomyces anomalus BS91, M. pulcherrima MPR3, and Aureobasidium pullulans PI1 were isolated from spontaneous olive fermentation and pomegranate, minimally processed. In detail, M. pulcherrima strain showed the best antifungal activity (disease incidence $(\mathrm{DI})=6.7 \%$, disease severity $(\mathrm{DS})=2.7 \%$ ), followed by W. anomalus BS91 and A. pullulans PI1, and all of these yeasts were capable of VOC production [106]. In particular, the antagonistic activity of $W$. anomalus seemed to be connected to a killer phenotype [106]. Enzyme secretion in the environment, such as b-1,3-glucanase, pectinase, and protease, was also reported for W. anomalus and A. pullulans [106], whereas, the activity of M. pulcherrima was probably associated with iron depletion [128]. In the patenting literature, two patents based on M. fructicola strain's biocontrol applications for viticultural applications have been reported [129].

Epiphytic Issatchenkia terricola yeasts isolated from 'Thompson Seedless' grapes' surface have shown the ability to reduce decay caused by B. cinerea up to $80 \%$ compared to the untreated control [104]. In another study, yeast and bacteria strains were isolated from fruits and leaves of the same cultivar without any signs of infection, and tested for potential applications in biocontrol [107]. Yeasts were identified as Candida membranifasciens Kh69 and Meyerozyma guilliermondii Ka21 and Kh59, while bacteria were Bacillus spp. Kh26 and Ralstonia spp. N1. All tested microbes were able to increase B. cinerea inhibition from $23.8 \%$ to $54.7 \%$. Among these, the highest level was found for Ralstonia spp. N1(54.7\%), while Bacillus spp. Kh26 and M. guilliermondii Ka21 and Kh59 showed inhibition below 50\% [107].

Still on the prokaryotic side, a bacterial strain, Paenibacillus pasadenensis R16, isolated from grapevine cultivar 'Barbera', has shown a reduction in disease incidence of grey mould by $27.5 \%$ [116]. It was also supposed that the main metabolite responsible for antifungal activity was farnesol which was never before reported to have biocontrol potential [116]. A large number of bacterial strains belonging to Bacillus spp. are reported to have antimicrobial activity against several plant phytopathogens [130-132]. In fact, a lot of commercial bio-fungicides, such as B. subtilis QST713 (Serenade ${ }^{\circledR}$, Bayer CropScience) and B. amyloliquefaciens FZB24 (Taegro ${ }^{\circledR}$, Novozymes), are now available and effective against grey mould on grapes. Recently, Chen et al. [115] demonstrated the ability of four Bacillus strains, isolated from various ecological niches, to control decay development in table grapes and other fruit crops. The most vigorous antifungal activity was recorded in B. subtilis Z-14 [115]. VOC production, enzyme, siderophores, and lipopeptide antibiotics were proposed as possible modes of action.

\subsection{Antimicrobial Compounds of Biological Origin}

Recently, there have been intense investigations conducted in the field of natural antimicrobials and their effectiveness. Many biological compounds have been tested for the bio-control of table grape spoilages. These compounds include classes of chemicals/matrices such as vegetal extracts, essential oils, and defence inducers (Table 4).

Among the vegetal compounds, volatiles generated from cellulose soaked with garlic hydro-alcoholic extract and its derived sulfur compounds have shown anti-grey mould activity in packaged table grapes both at 4 and $25^{\circ} \mathrm{C}$, during the 14 days of experimental trials [133]. However, organoleptic and sensorial adverse effects of this treatment have still not been investigated [133]. Cinnamic acid, extracted from cinnamon bark, is widely used as a food additive. Dipping the berries in a solution of $10 \mathrm{mM}$ cinnamic acid can significantly decrease the incidence of decay development up to half of that in control after four days of storage at $25^{\circ} \mathrm{C}$ [134]. Hinokitiol is a natural monoterpenoid mainly extracted from the wood of Cupressaceae. In a recent study [135], no decay was visible after $60 \mathrm{~h}$ at $22{ }^{\circ} \mathrm{C}$ in artificially wounded/inoculated table grape berries treated with a $3 \mathrm{~g} / \mathrm{L}$ hinokitiol solution [135]. 
Table 4. Main biological compounds investigated in the last ten years against grey mould decay on table grapes.

\begin{tabular}{|c|c|c|c|c|c|c|}
\hline & Biological Compounds & Concentration & Treatment & Cultivar & Effects & Ref. \\
\hline \multirow{3}{*}{ Vegetal extract } & $\begin{array}{l}\text { Hydro-alcoholic garlic extract } \\
\text { and derived sulfur compounds }\end{array}$ & $2 \mathrm{~mL}$ and $20 \mu \mathrm{L}$ & Volatiles release & Flame Seedless & $\begin{array}{l}\text { The treatment efficiently controlled the } \\
\text { decay in packed grapes at } 4 \text { and } 25^{\circ} \mathrm{C} \text { for } \\
14 \text { days }\end{array}$ & {$[133]$} \\
\hline & Cinnamic acid & $10 \mathrm{mM}$ & Dipping & Manai & $\begin{array}{l}\text { The treatment halved the decay incidence } \\
\text { after four days at } 25^{\circ} \mathrm{C}\end{array}$ & {$[134]$} \\
\hline & Hinokitiol & $3 \mathrm{~g} / \mathrm{L}$ & $\begin{array}{c}\text { Wound } \\
\text { inoculation }\end{array}$ & Manai & $\begin{array}{c}\text { No visible decay was reported after } 60 \mathrm{~h} \\
\text { at } 22{ }^{\circ} \mathrm{C}\end{array}$ & [135] \\
\hline Essential Oil & Mint EO & $500 \mu \mathrm{L} / \mathrm{L}$ & Volatiles release & Not specified & Reduction of decay in packed grapes & {$[136]$} \\
\hline \multirow[t]{4}{*}{ Other compounds } & Methyl jasmonate & $10 \mu \mathrm{mol} / \mathrm{L}$ & Volatiles release & Kyoho & Reduction of the decay incidence & {$[137]$} \\
\hline & Fulvic acid & $20 \mathrm{mg} / \mathrm{mL}$ & Dipping & Mare's milk & $\begin{array}{l}\text { Induction of resistance mainly through the } \\
\text { activation of phenylpropanoid pathway }\end{array}$ & [138] \\
\hline & Pterostilbene and Piceatannol & $50 \mathrm{mg} / \mathrm{L}$ & $\begin{array}{c}\text { Wound } \\
\text { inoculation }\end{array}$ & Mare's milk & Reduction of disease incidence and severity & [139] \\
\hline & Putrescine & $1-2 \mathrm{mM}$ & Dipping & Michele Palieri & $\begin{array}{l}\text { Combined with ultrasound, the treatment } \\
\text { maintained high levels of anthocyanins, } \\
\text { total phenolic content, antioxidant capacity, } \\
\text { sensory acceptability and reduced decay } \\
\text { incidence during storage }\end{array}$ & {$[23]$} \\
\hline \multirow[t]{3}{*}{ Edible coating } & Chitosan & - & Coating & Crimson & $\begin{array}{c}\text { Combined with UV-C irradiation, } \\
\text { the treatment increased the resveratrol } \\
\text { content, maintained sensorial quality, } \\
\text { and reduced fungal decay }\end{array}$ & [24] \\
\hline & Chitosan/Silica polymer & $0.5-1 \%$ & Spraying & Italia & $\begin{array}{l}\text { The treatment reduced natural infection; } \\
\text { no adverse effect in terms of quality } \\
\text { (titratable acidity [TA], total soluble solids } \\
\text { [TSS], berry color, mass loss, stem browning } \\
\text { and shattered berries) was observed }\end{array}$ & [140] \\
\hline & Chitosan + Salvia fruticosa Extract & 500 mg/L (SE) & Dipping & $\begin{array}{l}\text { Thompson } \\
\text { Seedless }\end{array}$ & $\begin{array}{l}\text { Control efficacy comparable to } \\
\text { thiabendazole, decreased the weight loss } \\
\text { during cold storage, preserved TSS and TA }\end{array}$ & [141] \\
\hline
\end{tabular}


Table 4. Cont

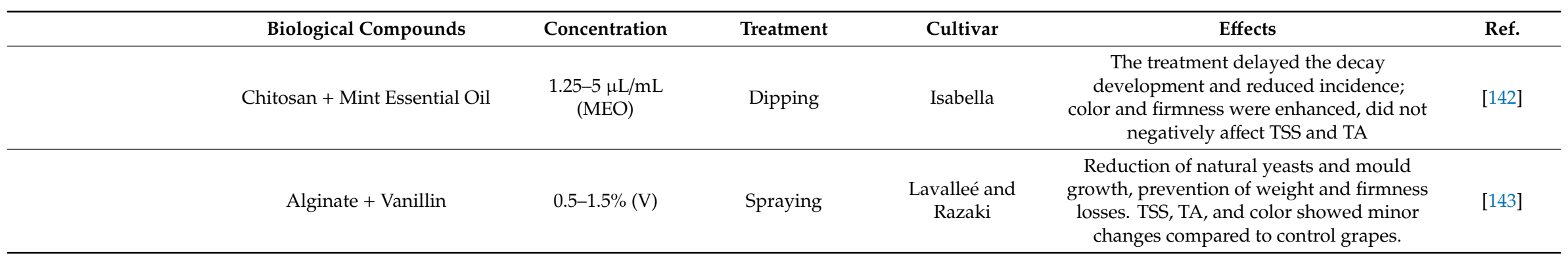


Essential oils (EOs) from many plants, such as thymus and lemongrass, have revealed great potential in post-harvest disease control [144]. In addition, the effect of mint EOs was recently investigated by using direct contact (e.g., dipping) and volatile methods (filter paper) [136]. In this study, EO released by the paper was more effective than the direct contact and was capable of inhibiting B. cinerea in artificially inoculated trials during nine days of shelf-life [136]. However, the effect on product flavour and consumer acceptance was not investigated.

Another research field involves the use of vegetal hormones, plant activators, and inner signalling molecules. These molecules act through a complex signalling network under the control of salicylic acid, ethylene, jasmonic acid, and phenylpropanoid pathways, which leads to the increase of specific secondary metabolites (e.g., flavonoids, soluble sugars, and phytoalexins). Methyl jasmonate is a volatile compound that mediates stress responses in plants and has shown to promote fungal resistance in various fruit crops. Recently, it was found to be effective in lessening the development of $B$. cinerea in artificially infected table grapes [137]. In this study, the fruits were packed in the presence of a filter paper soaked with a solution of methyl jasmonate at $10 \mu \mathrm{mol} / \mathrm{L}$ and stored at $25^{\circ} \mathrm{C}$ [137]. The disease incidence in the treated fruits after 24,36 , and $48 \mathrm{~h}$ was $41.7 \%, 60.6 \%$, and $86.5 \%$ of that in the control trial, respectively [137].

Fulvic acids (FA) are the soluble fraction of natural organic matter and are used in agriculture as a plant growth promoter and to control several plant diseases. Xu et al. [138] assayed different concentrations of FA as dipping solutions for wounded table grape fruits, subsequently sprinkled with a conidia suspension of $B$. cinerea. After six days of incubation at $22{ }^{\circ} \mathrm{C}$, the treatment with a solution at $20 \mathrm{mg} / \mathrm{mL}$ FA was found to be effective by reducing decay development [138]. The authors suggested that secondary metabolites produced by the berry mediate antifungal activity. However, the formation of necrotic spots was reported [138].

Among secondary metabolites, phytoalexins are synthesized by the plants as broad-spectrum inhibitors. Stilbenoids, including pterostilbene and piceatannol, are phytoalexins commonly found in vine leaves and wine [139]. "Mare's milk" table grapes treated with $50 \mathrm{mg} / \mathrm{L}$ pterostilbene did not show any sign of infection while piceatannol at the same concentration reduced grey mould disease by $75 \%$ after nine days storage at $22{ }^{\circ} \mathrm{C}$ [139]. These molecules seemed to be the most effective in a group of seven phenolic compounds, including resveratrol and coumarin [139].

Edible coatings made with natural polymers like chitosan or alginate can act as a cover material able to wrap the berry. Thus, these formulations can extend the shelf-life of fruit crops and maintain quality reducing water losses $[145,146]$. Chitosan is a linear polysaccharide composed of D-glucosamine and $\mathrm{N}$-acetyl-D-glucosamine linked by a $\beta-(1 \rightarrow 4)$ bond obtained by treating the exoskeleton of arthropods with alkaline solutions. Recently, it was found that chitosan-silica nanocomposite polymers can reduce the incidence of decay in grape berries by 59\% [140]. Moreover, this coating can be used to incorporate bioactive compounds. An additive effect of chitosan combined with Salvia fruticosa Mill. extract [141] and Mentha piperita or M. villosa essential oil [142] was reported. Alginate is another biocompatible and biodegradable polymer extracted from brown algae and used as a food additive with the code E401. It was demonstrated that the incorporation of vanillin, a phenolic compound, in a coating formulation prolongs the shelf life of table grapes until 35 days of storage, by reducing total yeasts and mould counts [143]. However, the retention of soluble solids, titratable acidity, firmness, and color was also enhanced.

\section{Conclusions and Future Directions}

Post-harvest fungal decay of fruits and vegetables is responsible for huge levels of economic loss and account consistently for large quantities of agro-food waste [147-150]. To improve economic, social, and environmental sustainability in the sector of table grapes, this review paper provides an overview of the wide plethora of physical, chemical, and bio-based solutions to improve the control of fungal pathogens and spoilage fungi. Each treatment has peculiar benefits and limitations that affect the concrete applications and shape different future perspectives [151]. For example, considering 
limitations, ozone does not always penetrate natural openings efficiently; condensation inside the package (MAP) increases the chance of microbial decay of produce; the antagonistic target of a biocontrol agent can have a strain-dependent spectrum. In some cases, the limitation is due to lack of harmonization of regulations and consumer acceptance (e.g., irradiation), and investment needs compared to the volume of production (e.g., CA storage) rather than of specific technological or biological issues [151].

As in other fields of food technology, an integrated management program (combining two or more different solutions) could be useful to minimize post-harvest losses caused by undesired fungal development $[147,152-155]$. Synergistic approaches have also been developed to reduce $B$. cinerea incidence in table grapes, adopting hurdles technology $[23,24,27,31,51]$. In other cases, one treatment aimed to reduce microbial contamination, while another was applied to stabilize fruit quality and the microbial population during cold storage and/or shelf-life [27,31,156]. Moreover, it is important to underline that a consistent range of solutions has been developed and tested on other fruits and vegetable [157-163] and, in several cases, could be tested/transferred for application on table grapes. Among the other green solutions, poorly explored in grapes, is the exploitation of lactic acid bacteria as biocontrol agents $[164,165]$ : prokaryotic organisms that received interest also in the light of additional positive side effects, e.g., probiotic activity and antagonistic activity against food-borne pathogens [166-170].

Author Contributions: Investigation, N.D.S., B.P., F.G., V.C., G.C., G.S. and P.R.; Conceptualization, N.D.S., B.P., F.G., M.C., V.T., V.S., V.C., G.C., G.S. and P.R.; Literature Search, N.D.S., B.P., F.G., M.C., V.T., V.S., V.C., G.C., G.S. and P.R.; Writing—Original Draft Preparation, N.D.S., V.C. and P.R.; Writing—Review and Editing, B.P., F.G., M.C., V.T., V.S., G.C. and G.S. All authors have read and agreed to the published version of the manuscript.

Funding: ABA MEDITERRANEA SCA was funded through Piani Operativi 2020 REG UE N 1308/13, REG UE N 2017/891, REG UE N 2017/892.

Acknowledgments: Pasquale Russo is the beneficiary of a grant by MIUR in the framework of 'AIM: Attraction and International Mobility' (PON R\&I2014-2020) (practice code D74I18000190001). The authors acknowledge (i) the two anonymous reviewers for their suggestions and comments, (ii) Massimo Franchi and Francesco De Marzo of the Institute of Sciences of Food Production-CNR for the skilled technical support provided during the realization of this work and (iii) Sergio Pelosi of the Institute of Sciences of Food Production-CNR for the critical reading.

Conflicts of Interest: The authors declare no conflict of interest.

\section{References}

1. Pezzuto, J.M. Grapes and human health: A perspective. J. Agric. Food Chem. 2008, 56, 6777-6784. [CrossRef] [PubMed]

2. FAO OIV. Table and Dried Grapes: World Data Available. Available online: http://www.fao.org/documents/ card/en/c/709ef071-6082-4434-91bf-4bc5b01380c6/ (accessed on 12 August 2020).

3. Ahmed, S.; Roberto, S.; Domingues, A.; Shahab, M.; Junior, O.; Sumida, C.; de Souza, R. Effects of Different Sulfur Dioxide Pads on Botrytis Mold in 'Italia' Table Grapes under Cold Storage. Horticulturae 2018, 4, 29. [CrossRef]

4. Williamson, B.; Tudzynski, B.; Tudzynski, P.; Van Kan, J.A.L. Botrytis cinerea: The cause of grey mould disease. Mol. Plant Pathol. 2007, 8, 561-580. [CrossRef] [PubMed]

5. Dean, R.; Van Kan, J.A.; Pretorius, Z.A.; Hammond-Kosack, K.E.; Di Pietro, A.; Spanu, P.D.; Rudd, J.J.; Dickman, M.; Kahmann, R.; Ellis, J.; et al. The Top 10 fungal pathogens in molecular plant pathology. Mol. Plant Pathol. 2012, 13, 414-430. [CrossRef] [PubMed]

6. Droby, S.; Lichter, A. Post-harvest Botrytis infection: Etiology, development and management. In Botrytis: Biology, Pathology and Control; Springer: Berlin/Heidelberg, Germany, 2007; pp. 349-367.

7. Domingues, A.; Roberto, S.; Ahmed, S.; Shahab, M.; José Chaves Junior, O.; Sumida, C.; de Souza, R. Postharvest Techniques to Prevent the Incidence of Botrytis Mold of ‘BRS Vitoria' Seedless Grape under Cold Storage. Horticulturae 2018, 4, 17. [CrossRef]

8. Capozzi, V.; Fiocco, D.; Amodio, M.L.; Gallone, A.; Spano, G. Bacterial Stressors in Minimally Processed Food. Int. J. Mol. Sci. 2009, 10, 3076-3105. [CrossRef] [PubMed] 
9. Francis, G.A.; Gallone, A.; Nychas, G.J.; Sofos, J.N.; Colelli, G.; Amodio, M.L.; Spano, G. Factors Affecting Quality and Safety of Fresh-Cut Produce. Crit. Rev. Food Sci. Nutr. 2012, 52, 595-610. [CrossRef]

10. Cavallo, D.P.; Cefola, M.; Pace, B.; Logrieco, A.F.; Attolico, G. Non-destructive and contactless quality evaluation of table grapes by a computer vision system. Comput. Electron. Agric. 2019, 156, 558-564. [CrossRef]

11. Ferrara, G.; Gallotta, A.; Pacucci, C.; Matarrese, A.M.S.; Mazzeo, A.; Giancaspro, A.; Gadaleta, A.; Piazzolla, F.; Colelli, G. The table grape 'Victoria' with a long shaped berry: A potential mutation with attractive characteristics for consumers. J. Sci. Food Agric. 2017, 97, 5398-5405. [CrossRef]

12. Piazzolla, F.; Pati, S.; Amodio, M.L.; Colelli, G. Effect of harvest time on table grape quality during on-vine storage. J. Sci. Food Agric. 2016, 96, 131-139. [CrossRef]

13. Iglesias-Carres, L.; Mas-Capdevila, A.; Bravo, F.I.; Aragonès, G.; Arola-Arnal, A.; Muguerza, B. A comparative study on the bioavailability of phenolic compounds from organic and nonorganic red grapes. Food Chem. 2019, 299, 125092. [CrossRef] [PubMed]

14. Council regulation (EC) No 834/2007 of 28 June 2007 on organic production and labelling of organic products and repealing regulation (EEC) No 2092/1. Off. J. Eur. Union 2007, 1-23.

15. Willer, H.; Schaack, D.; Lernoud, J. Organic Farming and Market Development in Europe and the European Union. In The World of Organic Agriculture-Statistics and Emerging Trends 2019; Willer, H., Lernoud, J., Eds.; Research Institute of Organic Agriculture FiBL and IFOAM-Organics International, Frick and Bonn: Rheinbreitbach, Germany, 2019; pp. 217-254.

16. Romanazzi, G.; Lichter, A.; Gabler, F.M.; Smilanick, J.L. Recent advances on the use of natural and safe alternatives to conventional methods to control postharvest gray mold of table grapes. Postharvest Biol. Technol. 2012, 63, 141-147. [CrossRef]

17. Lichter, A.; Kaplunov, T.; Zutahy, Y.; Lurie, S. Unique techniques developed in Israel for short- and long-term storage of table grapes. Isr. J. Plant Sci. 2016, 63, 2-6. [CrossRef]

18. Sonker, N.; Pandey, A.K.; Singh, P. Strategies to control post-harvest diseases of table grape: A review. J. Wine Res. 2016, 27, 105-122. [CrossRef]

19. Youssef, K.; Roberto, S.R.; Chiarotti, F.; Koyama, R.; Hussain, I.; de Souza, R.T. Control of Botrytis mold of the new seedless grape 'BRS Vitoria' during cold storage. Sci. Hortic. 2015, 193, 316-321. [CrossRef]

20. Crisosto, C.H.; Mitchell, F.G. Postharvest Handling Systems: Table grapes. In Postharvest Technology of Horticultural Crops; Kader, A.A., Ed.; University of California Agricultural and Natural Resources Pub: Davis, CA, USA, 2002; pp. 357-363.

21. Sabir, F.K.; Sabir, A. Quality response of table grapes (Vitis vinifera L.) during cold storage to postharvest cap stem excision and hot water treatments. Int. J. Food Sci. Technol. 2013, 48, 999-1006. [CrossRef]

22. Chiabrando, V.; Giacalone, G. Efficacy of hot water treatment as sanitizer for minimally processed table grape. J. Clean. Prod. 2020, 257, 120364. [CrossRef]

23. Bal, E.; Kok, D.; Torcuk, A.I. Postharvest putrescine and ultrasound treatments to improve quality and postharvest life of table grapes (Vitis vinifera L.) cv. Michele Palieri. J. Cent. Eur. Agric. 2017, 18. [CrossRef]

24. Freitas, P.M.; López-Gálvez, F.; Tudela, J.A.; Gil, M.I.; Allende, A. Postharvest treatment of table grapes with ultraviolet-C and chitosan coating preserves quality and increases stilbene content. Postharvest Biol. Technol. 2015, 105, 51-57. [CrossRef]

25. Romanazzi, G.; Nigro, F.; Ippolito, A. Effectiveness of a short hyperbaric treatment to control postharvest decay of sweet cherries and table grapes. Postharvest Biol. Technol. 2008, 49, 440-442. [CrossRef]

26. Guentzel, J.L.; Lam, K.L.; Callan, M.A.; Emmons, S.A.; Dunham, V.L. Postharvest management of gray mold and brown rot on surfaces of peaches and grapes using electrolyzed oxidizing water. Int. J. Food Microbiol. 2010, 143, 54-60. [CrossRef] [PubMed]

27. Teles, C.S.; Benedetti, B.C.; Gubler, W.D.; Crisosto, C.H. Prestorage application of high carbon dioxide combined with controlled atmosphere storage as a dual approach to control Botrytis cinerea in organic 'Flame Seedless' and 'Crimson Seedless' table grapes. Postharvest Biol. Technol. 2014, 89, 32-39. [CrossRef]

28. Vlassi, E.; Vlachos, P.; Kornaros, M. Effect of ozonation on table grapes preservation in cold storage. J. Food Sci. Technol. 2018, 55, 2031-2038. [CrossRef] [PubMed]

29. Feliziani, E.; Romanazzi, G.; Smilanick, J.L. Application of low concentrations of ozone during the cold storage of table grapes. Postharvest Biol. Technol. 2014, 93, 38-48. [CrossRef] 
30. Liguori, G.; Sortino, G.; De Pasquale, C.; Inglese, P. Effects of modified atmosphere packaging on quality parameters of minimally processed table grapes during cold storage. Adv. Hortic. Sci. 2015, 29, 152-154.

31. Admane, N.; Genovese, F.; Altieri, G.; Tauriello, A.; Trani, A.; Gambacorta, G.; Verrastro, V.; Di Renzo, G.C. Effect of ozone or carbon dioxide pre-treatment during long-term storage of organic table grapes with modified atmosphere packaging. LWT 2018, 98, 170-178. [CrossRef]

32. Cefola, M.; Pace, B. High CO2-modified atmosphere to preserve sensory and nutritional quality of organic table grape (cv. 'Italia') during storage and shelf-life. Eur. J. Hortic. Sci. 2016, 81, 197-203. [CrossRef]

33. Vilaplana, R.; Chicaiza, G.; Vaca, C.; Valencia-Chamorro, S. Combination of hot water treatment and chitosan coating to control anthracnose in papaya (Carica papaya L.) during the postharvest period. Crop Prot. 2020, 128, 105007. [CrossRef]

34. Kahramanoğlu, İ.; Chen, C.; Chen, Y.; Chen, J.; Gan, Z.; Wan, C. Improving Storability of "nanfeng" Mandarins by Treating with Postharvest Hot Water Dipping. J. Food Qual. 2020, 2020. [CrossRef]

35. Nigro, F.; Ippolito, A.; Lima, G. Use of UV-C light to reduce Botrytis storage rot of table grapes. Postharvest Biol. Technol. 1998, 13, 171-181. [CrossRef]

36. Amodio, M.L.; Rinaldi, R.; Colelli, G. Influence of atmosphere composition on quality attributes of ready-to-cook fresh-cut vegetable soup. In Proceedings of the IV International Conference on Managing Quality in Chains-The Integrated View on Fruits and Vegetables Quality, Bangkok, Thailand, 7-10 August 2006; pp. 677-684.

37. Daş, E.; Gürakan, G.C.; Bayındırlı, A. Effect of controlled atmosphere storage, modified atmosphere packaging and gaseous ozone treatment on the survival of Salmonella Enteritidis on cherry tomatoes. Food Microbiol. 2006, 23, 430-438. [CrossRef]

38. Cefola, M.; Pace, B.; Buttaro, D.; Santamaria, P.; Serio, F. Postharvest evaluation of soilless-grown table grape during storage in modified atmosphere. J. Sci. Food Agric. 2011, 91, 2153-2159. [CrossRef] [PubMed]

39. Cefola, M.; Renna, M.; Pace, B. Marketability of ready-to-eat cactus pear as affected by temperature and modified atmosphere. J. Food Sci. Technol. 2014, 51, 25-33. [CrossRef]

40. La Zazzera, M.; Amodio, M.L.; Colelli, G. Designing a modified atmosphere packaging (MAP) for fresh-cut artichokes. Adv. Hortic. Sci. 2015, 29, 24-29.

41. Retamales, J.; Defilippi, B.G.; Arias, M.; Castillo, P.; Manríquez, D. High-CO2 controlled atmospheres reduce decay incidence in Thompson Seedless and Red Globe table grapes. Postharvest Biol. Technol. 2003, 29, 177-182. [CrossRef]

42. Artés-Hernández, F.; Aguayo, E.; Artés, F. Alternative atmosphere treatments for keeping quality of 'Autumn seedless' table grapes during long-term cold storage. Postharvest Biol. Technol. 2004, 31, 59-67. [CrossRef]

43. Crisosto, C.H.; Garner, D.; Crisosto, G. High Carbon Dioxide Atmospheres Affect Stored “Thompson Seedless" Table Grapes. HortScience 2002, 37, 1074-1078. [CrossRef]

44. Palou, L.; Crisosto, C.H.; Smilanick, J.L.; Adaskaveg, J.E.; Zoffoli, J.P. Effects of continuous 0.3 ppm ozone exposure on decay development and physiological responses of peaches and table grapes in cold storage. Postharvest Biol. Technol. 2002, 24, 39-48. [CrossRef]

45. Carter, M.Q.; Chapman, M.H.; Gabler, F.; Brandl, M.T. Effect of sulfur dioxide fumigation on survival of foodborne pathogens on table grapes under standard storage temperature. Food Microbiol. 2015, 49, 189-196. [CrossRef]

46. Gao, H.; Hu, X.; Zhang, H.; Wang, S.; Liu, L. Study on sensitivity of table grapes to $\mathrm{SO}_{2}$. In Proceedings of the XXVI International Horticultural Congress: Issues and Advances in Postharvest Horticulture, Toronto, ON, Canada, 11-17 August 2002; pp. 541-548.

47. Zoffoli, J.P.; Latorre, B.A.; Naranjo, P. Hairline, a postharvest cracking disorder in table grapes induced by sulfur dioxide. Postharvest Biol. Technol. 2008, 47, 90-97. [CrossRef]

48. Lou, T.; Huang, W.; Wu, X.; Wang, M.; Zhou, L.; Lu, B.; Zheng, L.; Hu, Y. Monitoring, exposure and risk assessment of sulfur dioxide residues in fresh or dried fruits and vegetables in China. Food Addit. Contam. Part A 2017, 34, 918-927. [CrossRef] [PubMed]

49. EPA. Pesticide tolerance for sulfur dioxide. The Federal Register, 10 May 1989; pp. 384-385.

50. European Commission. Regulation (EC) No 1333/2008 of the European Parliament and of the Council of 16 December 2008 on food additives. Off. J. Eur. Community 2008, 50, 18.

51. Xu, D.; Yu, G.; Xi, P.; Kong, X.; Wang, Q.; Gao, L.; Jiang, Z. Synergistic Effects of Resveratrol and Pyrimethanil against Botrytis cinerea on Grape. Molecules 2018, 23, 1455. [CrossRef] [PubMed] 
52. Vitale, A.; Panebianco, A.; Polizzi, G. Baseline sensitivity and efficacy of fluopyram against Botrytis cinerea from table grape in Italy. Ann. Appl. Biol. 2016, 169, 36-45. [CrossRef]

53. Youssef, K.; Roberto, S.; Colombo, R.; Canteri, M.; Elsalam, K. Acibenzolar-S-methyl against Botrytis mold on table grapes in vitro and in vivo. Agron. Sci. Biotechnol. 2019, 5, 52. [CrossRef]

54. Lee, J.-S.; Kaplunov, T.; Zutahy, Y.; Daus, A.; Alkan, N.; Lichter, A. The significance of postharvest disinfection for prevention of internal decay of table grapes after storage. Sci. Hortic. 2015, 192, 346-349. [CrossRef]

55. Youssef, K.; Roberto, S.R. Salt strategies to control Botrytis mold of 'Benitaka' table grapes and to maintain fruit quality during storage. Postharvest Biol. Technol. 2014, 95, 95-102. [CrossRef]

56. Candir, E.; Ozdemir, A.E.; Kamiloglu, O.; Soylu, E.M.; Dilbaz, R.; Ustun, D. Modified atmosphere packaging and ethanol vapor to control decay of 'Red Globe' table grapes during storage. Postharvest Biol. Technol. 2012, 63, 98-106. [CrossRef]

57. Chen, S.; Wang, H.; Wang, R.; Fu, Q.; Zhang, W. Effect of gaseous chlorine dioxide (ClO2) with different concentrations and numbers of treatments on controlling berry decay and rachis browning of table grape. J. Food Process. Preserv. 2018, 42, e13662. [CrossRef]

58. Xu, J.; Zhang, Z.; Li, X.; Wei, J.; Wu, B. Effect of nitrous oxide against Botrytis cinerea and phenylpropanoid pathway metabolism in table grapes. Sci. Hortic. 2019, 254, 99-105. [CrossRef]

59. Vazquez-Hernandez, M.; Navarro, S.; Sanchez-Ballesta, M.T.; Merodio, C.; Escribano, M.I. Short-term high $\mathrm{CO} 2$ treatment reduces water loss and decay by modulating defense proteins and organic osmolytes in Cardinal table grape after cold storage and shelf-life. Sci. Hortic. 2018, 234, 27-35. [CrossRef]

60. Cayuela, J.A.; Vázquez, A.; Pérez, A.G.; García, J.M. Control of Table Grapes Postharvest Decay by Ozone Treatment and Resveratrol Induction: Food Sci. Technol. Int. 2010. [CrossRef]

61. Muri, S.D.; van der Voet, H.; Boon, P.E.; van Klaveren, J.D.; Brüschweiler, B.J. Comparison of human health risks resulting from exposure to fungicides and mycotoxins via food. Food Chem. Toxicol. 2009, 47, 2963-2974. [CrossRef] [PubMed]

62. Meena, R.S.; Kumar, S.; Datta, R.; Lal, R.; Vijayakumar, V.; Brtnicky, M.; Sharma, M.P.; Yadav, G.S.; Jhariya, M.K.; Jangir, C.K.; et al. Impact of Agrochemicals on Soil Microbiota and Management: A Review. Land 2020, 9, 34. [CrossRef]

63. Russo, P.; Berbegal, C.; De Ceglie, C.; Grieco, F.; Spano, G.; Capozzi, V. Pesticide Residues and Stuck Fermentation in Wine: New Evidences Indicate the Urgent Need of Tailored Regulations. Fermentation 2019, 5, 23. [CrossRef]

64. El Ghaouth, A.; Wilson, C.; Wisniewski, M. Biologically-Based Alternatives to Synthetic Fungicides for the Control of Postharvest diseases of Fruit and Vegetables. In Diseases of Fruits and Vegetables: Volume II: Diagnosis and Management; Naqvi, S.A.M.H., Ed.; Springer: Dordrecht, The Netherlands, 2004; pp. 511-535, ISBN 978-1-4020-2607-2.

65. Latorre, B.A.; Spadaro, I.; Rioja, M.E. Occurrence of resistant strains of Botrytis cinerea to anilinopyrimidine fungicides in table grapes in Chile. Crop Prot. 2002, 21, 957-961. [CrossRef]

66. Avenot, H.F.; Michailides, T.J. Progress in understanding molecular mechanisms and evolution of resistance to succinate dehydrogenase inhibiting (SDHI) fungicides in phytopathogenic fungi. Crop Prot. 2010, 29, 643-651. [CrossRef]

67. Amiri, A.; Heath, S.M.; Peres, N.A. Resistance to fluopyram, fluxapyroxad, and penthiopyrad in Botrytis cinerea from strawberry. Plant Dis. 2014, 98, 532-539. [CrossRef]

68. Ge, Y.-H.; Bi, Y.; Li, Y.-C.; Wang, Y. Resistance of harvested fruits and vegetables to diseases induced by ASM and its mechanism. Sci. Agric. Sin. 2012, 45, 3357-3362.

69. Cefola, M.; Pace, B.; Bugatti, V.; Vittoria, V. Active coatings for food packaging: A new strategy for table grape storage. Acta Hortic. 2015, 1071, 121-127. [CrossRef]

70. Gorrasi, G.; Bugatti, V.; Vertuccio, L.; Vittoria, V.; Pace, B.; Cefola, M.; Quintieri, L.; Bernardo, P.; Clarizia, G. Active packaging for table grapes: Evaluation of antimicrobial performances of packaging for shelf life of the grapes under thermal stress. Food Packag. Shelf Life 2020, 25, 100545. [CrossRef]

71. Smith, D.J.; Ernst, W.; Herges, G.R. Chloroxyanion Residues in Cantaloupe and Tomatoes after Chlorine Dioxide Gas Sanitation. J. Agric. Food Chem. 2015, 63, 9640-9649. [CrossRef]

72. Miller, F.A.; Silva, C.L.; Brandão, T.R. A review on ozone-based treatments for fruit and vegetables preservation. Food Eng. Rev. 2013, 5, 77-106. [CrossRef] 
73. Aslam, R.; Alam, M.S.; Saeed, P.A. Sanitization Potential of Ozone and Its Role in Postharvest Quality Management of Fruits and Vegetables. Food Eng. Rev. 2020, 12, 48-67. [CrossRef]

74. Ozkan, R.; Smilanick, J.L.; Karabulut, O.A. Toxicity of ozone gas to conidia of Penicillium digitatum, Penicillium italicum, and Botrytis cinerea and control of gray mold on table grapes. Postharvest Biol. Technol. 2011, 60, 47-51. [CrossRef]

75. Gabler, F.M.; Smilanick, J.L.; Mansour, M.F.; Karaca, H. Influence of fumigation with high concentrations of ozone gas on postharvest gray mold and fungicide residues on table grapes. Postharvest Biol. Technol. 2010, 55, 85-90. [CrossRef]

76. Karaca, H. The Effects of Ozone-Enriched Storage Atmosphere on Pesticide Residues and Physicochemical Properties of Table Grapes. Ozone Sci. Eng. 2019, 41, 404-414. [CrossRef]

77. Zhang, J.; Wei, Y.; Fang, Z. Ozone pollution: A major health hazard worldwide. Front. Immunol. 2019, 10, 2518. [CrossRef]

78. Russo, P.; Fares, C.; Longo, A.; Spano, G.; Capozzi, V. Lactobacillus plantarum with Broad Antifungal Activity as a Protective Starter Culture for Bread Production. Foods 2017, 6, 110. [CrossRef]

79. Linares-Morales, J.R.; Gutiérrez-Méndez, N.; Rivera-Chavira, B.E.; Pérez-Vega, S.B.; Nevárez-Moorillón, G.V. Biocontrol Processes in Fruits and Fresh Produce, the Use of Lactic Acid Bacteria as a Sustainable Option. Front. Sustain. Food Syst. 2018, 2, 50. [CrossRef]

80. Raveau, R.; Fontaine, J.; Lounès-Hadj Sahraoui, A. Essential Oils as Potential Alternative Biocontrol Products against Plant Pathogens and Weeds: A Review. Foods 2020, 9, 365. [CrossRef] [PubMed]

81. Ling, L.; Han, X.; Li, X.; Zhang, X.; Wang, H.; Zhang, L.; Cao, P.; Wu, Y.; Wang, X.; Zhao, J.; et al. A Streptomyces sp. NEAU-HV9: Isolation, Identification, and Potential as a Biocontrol Agent against Ralstonia solanacearum of Tomato Plants. Microorganisms 2020, 8, 351. [CrossRef] [PubMed]

82. Into, P.; Khunnamwong, P.; Jindamoragot, S.; Am-in, S.; Intanoo, W.; Limtong, S. Yeast Associated with Rice Phylloplane and Their Contribution to Control of Rice Sheath Blight Disease. Microorganisms 2020, 8, 362. [CrossRef] [PubMed]

83. Arena, M.P.; Russo, P.; Spano, G.; Capozzi, V. Exploration of the Microbial Biodiversity Associated with North Apulian Sourdoughs and the Effect of the Increasing Number of Inoculated Lactic Acid Bacteria Strains on the Biocontrol against Fungal Spoilage. Fermentation 2019, 5, 97. [CrossRef]

84. Arena, M.P.; Russo, P.; Spano, G.; Capozzi, V. From Microbial Ecology to Innovative Applications in Food Quality Improvements: The Case of Sourdough as a Model Matrix. J-Multidiscip. Sci. J. 2020, 3, 3. [CrossRef]

85. Gálvez, A.; Abriouel, H.; Benomar, N.; Lucas, R. Microbial antagonists to food-borne pathogens and biocontrol. Curr. Opin. Biotechnol. 2010, 21, 142-148. [CrossRef]

86. Berbegal, C.; Spano, G.; Tristezza, M.; Grieco, F.; Capozzi, V. Microbial Resources and Innovation in the Wine Production Sector. S. Afr. J. Enol. Vitic. 2017, 38, 156-166. [CrossRef]

87. Garofalo, C.; Russo, P.; Beneduce, L.; Massa, S.; Spano, G.; Capozzi, V. Non-Saccharomyces biodiversity in wine and the 'microbial terroir': A survey on Nero di Troia wine from the Apulian region, Italy. Ann. Microbiol. 2016, 66, 143-150. [CrossRef]

88. Benito, Á.; Calderón, F.; Benito, S. The Influence of Non-Saccharomyces Species on Wine Fermentation Quality Parameters. Fermentation 2019, 5, 54. [CrossRef]

89. Berbegal, C.; Spano, G.; Fragasso, M.; Grieco, F.; Russo, P.; Capozzi, V. Starter cultures as biocontrol strategy to prevent Brettanomyces bruxellensis proliferation in wine. Appl. Microbiol. Biotechnol. 2018, 102, 569-576. [CrossRef]

90. Di Toro, M.R.; Capozzi, V.; Beneduce, L.; Alexandre, H.; Tristezza, M.; Durante, M.; Tufariello, M.; Grieco, F.; Spano, G. Intraspecific biodiversity and 'spoilage potential' of Brettanomyces bruxellensis in Apulian wines. LWT Food Sci. Technol. 2015, 60, 102-108. [CrossRef]

91. Russo, P.; Fragasso, M.; Berbegal, C.; Grieco, F.; Spano, G.; Capozzi, V. Microorganisms Able to Produce Biogenic Amines and Factors Affecting Their Activity. In Biogenic Amines in Food; RCS Publishing: Cambridge, UK, 2019; pp. 18-40.

92. Russo, P.; Capozzi, V.; Spano, G.; Corbo, M.R.; Sinigaglia, M.; Bevilacqua, A. Metabolites of Microbial Origin with an Impact on Health: Ochratoxin A and Biogenic Amines. Front. Microbiol. 2016, 7, 482. [CrossRef] [PubMed] 
93. Berbegal, C.; Borruso, L.; Fragasso, M.; Tufariello, M.; Russo, P.; Brusetti, L.; Spano, G.; Capozzi, V. A Metagenomic-Based Approach for the Characterization of Bacterial Diversity Associated with Spontaneous Malolactic Fermentations in Wine. Int. J. Mol. Sci. 2019, 20, 3980. [CrossRef] [PubMed]

94. Zhang, S.; Chen, X.; Zhong, Q.; Zhuang, X.; Bai, Z. Microbial Community Analyses Associated with Nine Varieties of Wine Grape Carposphere Based on High-Throughput Sequencing. Microorganisms 2019, 7, 668. [CrossRef] [PubMed]

95. Garofalo, C.; Berbegal, C.; Grieco, F.; Tufariello, M.; Spano, G.; Capozzi, V. Selection of indigenous yeast strains for the production of sparkling wines from native Apulian grape varieties. Int. J. Food Microbiol. 2018, 285, 7-17. [CrossRef]

96. Gómez Brandón, M.; Aira, M.; Kolbe, A.R.; de Andrade, N.; Pérez-Losada, M.; Domínguez, J. Rapid Bacterial Community Changes during Vermicomposting of Grape Marc Derived from Red Winemaking. Microorganisms 2019, 7, 473. [CrossRef] [PubMed]

97. Ab Rahman, S.F.; Singh, E.; Pieterse, C.M.J.; Schenk, P.M. Emerging microbial biocontrol strategies for plant pathogens. Plant Sci. Int. J. Exp. Plant Biol. 2018, 267, 102-111. [CrossRef]

98. Bleve, G.; Grieco, F.; Cozzi, G.; Logrieco, A.; Visconti, A. Isolation of epiphytic yeasts with potential for biocontrol of Aspergillus carbonarius and A. niger on grape. Int. J. Food Microbiol. 2006, 108, 204-209. [CrossRef]

99. Berbegal, C.; Garofalo, C.; Russo, P.; Pati, S.; Capozzi, V.; Spano, G. Use of Autochthonous Yeasts and Bacteria in Order to Control Brettanomyces bruxellensis in Wine. Fermentation 2017, 3, 65. [CrossRef]

100. Nally, M.C.; Pesce, V.M.; Maturano, Y.P.; Assaf, L.R.; Toro, M.E.; de Figueroa, L.C.; Vazquez, F. Antifungal modes of action of Saccharomyces and other biocontrol yeasts against fungi isolated from sour and grey rots. Int. J. Food Microbiol. 2015, 204, 91-100. [CrossRef] [PubMed]

101. Pretscher, J.; Fischkal, T.; Branscheidt, S.; Jäger, L.; Kahl, S.; Schlander, M.; Thines, E.; Claus, H. Yeasts from Different Habitats and Their Potential as Biocontrol Agents. Fermentation 2018, 4, 31. [CrossRef]

102. López-Seijas, J.; García-Fraga, B.; da Silva, A.F.; Sieiro, C. Wine Lactic Acid Bacteria with Antimicrobial Activity as Potential Biocontrol Agents against Fusarium oxysporum f. sp. lycopersici. Agronomy 2020, 10, 31. [CrossRef]

103. Leyva Salas, M.; Mounier, J.; Valence, F.; Coton, M.; Thierry, A.; Coton, E. Antifungal Microbial Agents for Food Biopreservation-A Review. Microorganisms 2017, 5, 37. [CrossRef]

104. Vargas, M.; Garrido, F.; Zapata, N.; Tapia, M. Isolation and selection of epiphytic yeast for biocontrol of Botrytis cinerea pers. on table grapes. Chil. J. Agric. Res. 2012, 72, 332. [CrossRef]

105. Parafati, L.; Vitale, A.; Restuccia, C.; Cirvilleri, G. Biocontrol ability and action mechanism of food-isolated yeast strains against Botrytis cinerea causing post-harvest bunch rot of table grape. Food Microbiol. 2015, 47, 85-92. [CrossRef]

106. Parafati, L.; Vitale, A.; Polizzi, G.; Restuccia, C.; Cirvilleri, G. Understanding the mechanism of biological control of postharvest phytopathogenic moulds promoted by food isolated yeasts. Acta Hortic. 2016, 93-100. [CrossRef]

107. Kasfi, K.; Taheri, P.; Jafarpour, B.; Tarighi, S. Identification of epiphytic yeasts and bacteria with potential for biocontrol of grey mold disease on table grapes caused by Botrytis cinerea. Span. J. Agric. Res. 2018, 16, 23. [CrossRef]

108. Nally, M.C.; Pesce, V.M.; Maturano, Y.P.; Muñoz, C.J.; Combina, M.; Toro, M.E.; de Figueroa, L.I.C.; Vazquez, F. Biocontrol of Botrytis cinerea in table grapes by non-pathogenic indigenous Saccharomyces cerevisiae yeasts isolated from viticultural environments in Argentina. Postharvest Biol. Technol. 2012, 64, 40-48. [CrossRef]

109. Cordero-Bueso, G.; Mangieri, N.; Maghradze, D.; Foschino, R.; Valdetara, F.; Cantoral, J.M.; Vigentini, I. Wild Grape-Associated Yeasts as Promising Biocontrol Agents against Vitis vinifera Fungal Pathogens. Front. Microbiol. 2017, 8. [CrossRef]

110. Lemos Junior, W.J.F.; Bovo, B.; Nadai, C.; Crosato, G.; Carlot, M.; Favaron, F.; Giacomini, A.; Corich, V. Biocontrol Ability and Action Mechanism of Starmerella bacillaris (Synonym Candida zemplinina) Isolated from Wine Musts against Gray Mold Disease Agent Botrytis cinerea on Grape and Their Effects on Alcoholic Fermentation. Front. Microbiol. 2016, 7. [CrossRef] [PubMed]

111. Qin, X.; Xiao, H.; Xue, C.; Yu, Z.; Yang, R.; Cai, Z.; Si, L. Biocontrol of gray mold in grapes with the yeast Hanseniaspora uvarum alone and in combination with salicylic acid or sodium bicarbonate. Postharvest Biol. Technol. 2015, 100, 160-167. [CrossRef] 
112. Mewa-Ngongang, M.; Du Plessis, H.W.; Ntwampe, S.K.O.; Chidi, B.S.; Hutchinson, U.F.; Mekuto, L.; Jolly, N.P. Fungistatic and Fungicidal Properties of Candida pyralidae Y1117, Pichia kluyveri Y1125 and Pichia kluyveri Y1164 on the Biocontrol of Botrytis Cinereal. In Proceedings of the 10th International Conference on Advances in Science, Engineering, Technology and Healthcare (ASETH-18), Cape Town, South Africa, 19-20 November 2018; pp. 19-20.

113. Mewa-Ngongang, M.; Du Plessis, H.W.; Ntwampe, S.K.O.; Chidi, B.S.; Hutchinson, U.F.; Mekuto, L.; Jolly, N.P. The Use of Candida pyralidae and Pichia kluyveri to Control Spoilage Microorganisms of Raw Fruits Used for Beverage Production. Foods 2019, 8, 454. [CrossRef] [PubMed]

114. Zhou, Q.; Fu, M.; Xu, M.; Chen, X.; Qiu, J.; Wang, F.; Yan, R.; Wang, J.; Zhao, S.; Xin, X. Application of antagonist Bacillus amyloliquefaciens NCPSJ7 against Botrytis cinerea in postharvest Red Globe grapes. Food Sci. Nutr. 2020, 8, 1499-1508. [CrossRef] [PubMed]

115. Chen, X.; Wang, Y.; Gao, Y.; Gao, T.; Zhang, D. Inhibitory Abilities of Bacillus Isolates and Their Culture Filtrates against the Gray Mold Caused by Botrytis cinerea on Postharvest Fruit. Plant Pathol. J. 2019, 35, 425-436. [CrossRef]

116. Passera, A.; Venturini, G.; Battelli, G.; Casati, P.; Penaca, F.; Quaglino, F.; Bianco, P.A. Competition assays revealed Paenibacillus pasadenensis strain R16 as a novel antifungal agent. Microbiol. Res. 2017, 198, 16-26. [CrossRef]

117. Walker, G.M.; Stewart, G.G. Saccharomyces cerevisiae in the Production of Fermented Beverages. Beverages 2016, 2, 30. [CrossRef]

118. Albertin, W.; Marullo, P.; Aigle, M.; Dillmann, C.; de Vienne, D.; Bely, M.; Sicard, D. Population Size Drives Industrial Saccharomyces cerevisiae Alcoholic Fermentation and Is under Genetic Control. Appl. Environ. Microbiol. 2011, 77, 2772-2784. [CrossRef]

119. Feyder, S.; De Craene, J.-O.; Bär, S.; Bertazzi, D.L.; Friant, S. Membrane Trafficking in the Yeast Saccharomyces cerevisiae Model. Int. J. Mol. Sci. 2015, 16, 1509-1525. [CrossRef]

120. Tristezza, M.; Tufariello, M.; Capozzi, V.; Spano, G.; Mita, G.; Grieco, F. The Oenological Potential of Hanseniaspora uvarum in Simultaneous and Sequential Co-fermentation with Saccharomyces cerevisiae for Industrial Wine Production. Front. Microbiol. 2016, 7. [CrossRef]

121. Capozzi, V.; Berbegal, C.; Tufariello, M.; Grieco, F.; Spano, G. Impact of co-inoculation of Saccharomyces cerevisiae, Hanseniaspora uvarum and Oenococcus oeni autochthonous strains in controlled multi starter grape must fermentations. LWT 2019, 109, 241-249. [CrossRef]

122. Liu, H.M.; Guo, J.H.; Cheng, Y.J.; Luo, L.; Liu, P.; Wang, B.Q.; Deng, B.X.; Long, C.A. Control of gray mold of grape by Hanseniaspora uvarum and its effects on postharvest quality parameters. Ann. Microbiol. 2010, 60, 31-35. [CrossRef]

123. Liu, H.M.; Guo, J.H.; Luo, L.; Liu, P.; Wang, B.Q.; Cheng, Y.J.; Deng, B.X.; Long, C.A. Improvement of Hanseniaspora uvarum biocontrol activity against gray mold by the addition of ammonium molybdate and the possible mechanisms involved. Crop Prot. 2010, 29, 277-282. [CrossRef]

124. Russo, P.; Englezos, V.; Capozzi, V.; Pollon, M.; Río Segade, S.; Rantsiou, K.; Spano, G.; Cocolin, L. Effect of mixed fermentations with Starmerella bacillaris and Saccharomyces cerevisiae on management of malolactic fermentation. Food Res. Int. 2020, 134, 109246. [CrossRef] [PubMed]

125. Russo, P.; Tufariello, M.; Renna, R.; Tristezza, M.; Taurino, M.; Palombi, L.; Capozzi, V.; Rizzello, C.G.; Grieco, F. New Insights into the Oenological Significance of Candida zemplinina: Impact of Selected Autochthonous Strains on the Volatile Profile of Apulian Wines. Microorganisms 2020, 8, 628. [CrossRef]

126. Masneuf-Pomarede, I.; Juquin, E.; Miot-Sertier, C.; Renault, P.; Laizet, Y.; Salin, F.; Alexandre, H.; Capozzi, V.; Cocolin, L.; Colonna-Ceccaldi, B.; et al. The yeast Starmerella bacillaris (synonym Candida zemplinina) shows high genetic diversity in winemaking environments. FEMS Yeast Res. 2015, 15. [CrossRef]

127. Mateus, D.; Sousa, S.; Coimbra, C.; Rogerson, F.S.; Simões, J. Identification and Characterization of Non-Saccharomyces Species Isolated from Port Wine Spontaneous Fermentations. Foods 2020, 9, 120. [CrossRef]

128. Saravanakumar, D.; Ciavorella, A.; Spadaro, D.; Garibaldi, A.; Gullino, M.L. Metschnikowia pulcherrima strain MACH1 outcompetes Botrytis cinerea, Alternaria alternata and Penicillium expansum in apples through iron depletion. Postharvest Biol. Technol. 2008, 49, 121-128. [CrossRef]

129. Roudil, L.; Russo, P.; Berbegal, C.; Albertin, W.; Spano, G.; Capozzi, V. Non-Saccharomyces Commercial Starter Cultures: Scientific Trends, Recent Patents and Innovation in the Wine Sector. Recent Pat. Food Nutr. Agric. 2019, 11. [CrossRef] 
130. Compant, S.; Duffy, B.; Nowak, J.; Clément, C.; Barka, E.A. Use of plant growth-promoting bacteria for biocontrol of plant diseases: Principles, mechanisms of action, and future prospects. Appl. Environ. Microbiol. 2005, 71, 4951-4959. [CrossRef]

131. Khan, N.; Maymon, M.; Hirsch, A.M. Combating Fusarium Infection Using Bacillus-Based Antimicrobials. Microorganisms 2017, 5, 75. [CrossRef] [PubMed]

132. Khan, N.; Martínez-Hidalgo, P.; Ice, T.A.; Maymon, M.; Humm, E.A.; Nejat, N.; Sanders, E.R.; Kaplan, D.; Hirsch, A.M. Antifungal Activity of Bacillus Species Against Fusarium and Analysis of the Potential Mechanisms Used in Biocontrol. Front. Microbiol. 2018, 9. [CrossRef] [PubMed]

133. Campa-Siqueiros, P.; Vallejo-Cohen, S.; Corrales-Maldonado, C.; Martínez-Téllez, M.Á.; Vargas-Arispuro, I.; Ávila-Quezada, G. Reduction in the incidence of grey mold in table grapes due to the volatile effect of a garlic extract. Rev. Mex. Fitopatol. Mex. J. Phytopathol. 2017, 35. [CrossRef]

134. Zhang, Z.; Qin, G.; Li, B.; Tian, S. Effect of Cinnamic Acid for Controlling Gray Mold on Table Grape and Its Possible Mechanisms of Action. Curr. Microbiol. 2015, 71, 396-402. [CrossRef]

135. Wang, Y.; Liu, X.; Chen, T.; Xu, Y.; Tian, S. Antifungal effects of hinokitiol on development of Botrytis cinerea in vitro and in vivo. Postharvest Biol. Technol. 2020, 159, 111038. [CrossRef]

136. Xueuan, R.; Dandan, S.; Zhuo, L.; Qingjun, K. Effect of mint oil against Botrytis cinerea on table grapes and its possible mechanism of action. Eur. J. Plant Pathol. 2018, 151, 321-328. [CrossRef]

137. Jiang, L.; Jin, P.; Wang, L.; Yu, X.; Wang, H.; Zheng, Y. Methyl jasmonate primes defense responses against Botrytis cinerea and reduces disease development in harvested table grapes. Sci. Hortic. 2015, 192, $218-223$. [CrossRef]

138. Xu, D.; Deng, Y.; Xi, P.; Yu, G.; Wang, Q.; Zeng, Q.; Jiang, Z.; Gao, L. Fulvic acid-induced disease resistance to Botrytis cinerea in table grapes may be mediated by regulating phenylpropanoid metabolism. Food Chem. 2019, 286, 226-233. [CrossRef]

139. Xu, D.; Deng, Y.; Han, T.; Jiang, L.; Xi, P.; Wang, Q.; Jiang, Z.; Gao, L. In vitro and in vivo effectiveness of phenolic compounds for the control of postharvest gray mold of table grapes. Postharvest Biol. Technol. 2018, 139, 106-114. [CrossRef]

140. Youssef, K.; de Oliveira, A.G.; Tischer, C.A.; Hussain, I.; Roberto, S.R. Synergistic effect of a novel chitosan/silica nanocomposites-based formulation against gray mold of table grapes and its possible mode of action. Int. J. Biol. Macromol. 2019, 141, 247-258. [CrossRef]

141. Kanetis, L.; Exarchou, V.; Charalambous, Z.; Goulas, V. Edible coating composed of chitosan and Salvia fruticosa Mill. extract for the control of grey mould of table grapes. J. Sci. Food Agric. 2017, 97, 452-460. [CrossRef] [PubMed]

142. Guerra, I.C.D.; De Oliveira, P.D.L.; Santos, M.M.F.; Lúcio, A.S.S.C.; Tavares, J.F.; Barbosa-Filho, J.M.; Madruga, M.S.; De Souza, E.L. The effects of composite coatings containing chitosan and Mentha (piperita L. or $x$ villosa Huds) essential oil on postharvest mold occurrence and quality of table grape cv. Isabella. Innov. Food Sci. Emerg. Technol. 2016, 34, 112-121. [CrossRef]

143. Takma, D.K.; Korel, F. Impact of preharvest and postharvest alginate treatments enriched with vanillin on postharvest decay, biochemical properties, quality and sensory attributes of table grapes. Food Chem. 2017, 221, 187-195. [CrossRef] [PubMed]

144. Sivakumar, D.; Bautista-Baños, S. A review on the use of essential oils for postharvest decay control and maintenance of fruit quality during storage. Crop Prot. 2014, 64, 27-37. [CrossRef]

145. Zhou, R.; Mo, Y.; Li, Y.; Zhao, Y.; Zhang, G.; Hu, Y. Quality and internal characteristics of Huanghua pears (Pyrus pyrifolia Nakai, cv. Huanghua) treated with different kinds of coatings during storage. Postharvest Biol. Technol. 2008, 49, 171-179. [CrossRef]

146. Azarakhsh, N.; Osman, A.; Ghazali, H.M.; Tan, C.P.; Mohd Adzahan, N. Lemongrass essential oil incorporated into alginate-based edible coating for shelf-life extension and quality retention of fresh-cut pineapple. Postharvest Biol. Technol. 2014, 88, 1-7. [CrossRef]

147. Sharma, R.R.; Singh, D.; Singh, R. Biological control of postharvest diseases of fruits and vegetables by microbial antagonists: A review. Biol. Control 2009, 50, 205-221. [CrossRef]

148. Underhill, S.J.R.; Joshua, L.; Zhou, Y. A Preliminary Assessment of Horticultural Postharvest Market Loss in the Solomon Islands. Horticulturae 2019, 5, 5. [CrossRef] 
149. Kumar, D.; Kalita, P. Reducing Postharvest Losses during Storage of Grain Crops to Strengthen Food Security in Developing Countries. Foods 2017, 6, 8. [CrossRef]

150. McKenzie, T.J.; Singh-Peterson, L.; Underhill, S.J.R. Quantifying Postharvest Loss and the Implication of Market-Based Decisions: A Case Study of Two Commercial Domestic Tomato Supply Chains in Queensland, Australia. Horticulturae 2017, 3, 44. [CrossRef]

151. Mahajan, P.V.; Caleb, O.J.; Singh, Z.; Watkins, C.B.; Geyer, M. Postharvest treatments of fresh produce. Philos. Transact. R. Soc. A Math. Phys. Eng. Sci. 2014, 372. [CrossRef] [PubMed]

152. Romanazzi, G.; Smilanick, J.L.; Feliziani, E.; Droby, S. Integrated management of postharvest gray mold on fruit crops. Postharvest Biol. Technol. 2016, 113, 69-76. [CrossRef]

153. Shi, Z.; Deng, J.; Wang, F.; Liu, Y.; Jiao, J.; Wang, L.; Zhang, J. Individual and combined effects of bamboo vinegar and peach gum on postharvest grey mould caused by Botrytis cinerea in blueberry. Postharvest Biol. Technol. 2019, 155, 86-93. [CrossRef]

154. Panebianco, S.; Vitale, A.; Polizzi, G.; Scala, F.; Cirvilleri, G. Enhanced control of postharvest citrus fruit decay by means of the combined use of compatible biocontrol agents. Biol. Control 2015, 84, 19-27. [CrossRef]

155. Zhang, X.; Min, D.; Li, F.; Ji, N.; Meng, D.; Li, L. Synergistic effects of L-arginine and methyl salicylate on alleviating postharvest disease caused by Botrysis cinerea in tomato fruit. J. Agric. Food Chem. 2017, 65, 4890-4896. [CrossRef]

156. Liguori, G.; D'Aquino, S.; Sortino, G.; De Pasquale, C.; Inglese, P. Effects of passive and active modified atmosphere packaging conditions on quality parameters of minimally processed table grapes during cold storage. J. Berry Res. 2015, 5, 131-143. [CrossRef]

157. Taghavi, T.; Kim, C.; Rahemi, A. Role of Natural Volatiles and Essential Oils in Extending Shelf Life and Controlling Postharvest Microorganisms of Small Fruits. Microorganisms 2018, 6, 104. [CrossRef]

158. Chiabrando, V.; Garavaglia, L.; Giacalone, G. The Postharvest Quality of Fresh Sweet Cherries and Strawberries with an Active Packaging System. Foods 2019, 8, 335. [CrossRef]

159. Chang, X.; Lu, Y.; Li, Q.; Lin, Z.; Qiu, J.; Peng, C.; Brennan, C.S.; Guo, X. The Combination of Hot Air and Chitosan Treatments on Phytochemical Changes during Postharvest Storage of 'Sanhua' Plum Fruits. Foods 2019, 8, 338. [CrossRef]

160. Sharma, S.; Pareek, S.; Sagar, N.A.; Valero, D.; Serrano, M. Modulatory Effects of Exogenously Applied Polyamines on Postharvest Physiology, Antioxidant System and Shelf Life of Fruits: A Review. Int. J. Mol. Sci. 2017, 18, 1789. [CrossRef]

161. Camele, I.; Altieri, L.; De Martino, L.; De Feo, V.; Mancini, E.; Rana, G.L. In Vitro Control of Post-Harvest Fruit Rot Fungi by Some Plant Essential Oil Components. Int. J. Mol. Sci. 2012, 13, 2290-2300. [CrossRef] [PubMed]

162. Zhang, H.; Li, R.; Liu, W. Effects of Chitin and Its Derivative Chitosan on Postharvest Decay of Fruits: A Review. Int. J. Mol. Sci. 2011, 12, 917-934. [CrossRef] [PubMed]

163. Mamoci, E.; Cavoski, I.; Simeone, V.; Mondelli, D.; Al-Bitar, L.; Caboni, P. Chemical Composition and In Vitro Activity of Plant Extracts from Ferula communis and Dittrichia viscosa against Postharvest Fungi. Molecules 2011, 16, 2609-2625. [CrossRef]

164. Ghosh, R.; Barman, S.; Mukhopadhyay, A.; Mandal, N.C. Biological control of fruit-rot of jackfruit by rhizobacteria and food grade lactic acid bacteria. Biol. Control 2015, 83, 29-36. [CrossRef]

165. Zhimo, V.Y.; Biasi, A.; Kumar, A.; Feygenberg, O.; Salim, S.; Vero, S.; Wisniewski, M.; Droby, S. Yeasts and Bacterial Consortia from Kefir Grains Are Effective Biocontrol Agents of Postharvest Diseases of Fruits. Microorganisms 2020, 8, 428. [CrossRef] [PubMed]

166. Iglesias, M.B.; Abadias, M.; Anguera, M.; Sabata, J.; Viñas, I. Antagonistic effect of probiotic bacteria against foodborne pathogens on fresh-cut pear. LWT_Food Sci. Technol. 2017, 81, 243-249. [CrossRef]

167. Grieco, F.; Castellano, M.A.; Di Sansebastiano, G.P.; Maggipinto, G.; Neuhaus, J.-M.; Martelli, G.P. Subcellular localization and in vivo identification of the putative movement protein of olive latent virus 2. J. Gen. Virol. 1999, 80, 1103-1109. [CrossRef]

168. Russo, P.; Peña, N.; de Chiara, M.L.V.; Amodio, M.L.; Colelli, G.; Spano, G. Probiotic lactic acid bacteria for the production of multifunctional fresh-cut cantaloupe. Food Res. Int. 2015, 77, 762-772. [CrossRef] 
169. Russo, P.; de Chiara, M.L.V.; Vernile, A.; Amodio, M.L.; Arena, M.P.; Capozzi, V.; Massa, S.; Spano, G. Fresh-Cut Pineapple as a New Carrier of Probiotic Lactic Acid Bacteria. BioMed Res. Int. 2014, 2014, 1-9. [CrossRef]

170. Arena, M.P.; Capozzi, V.; Russo, P.; Drider, D.; Spano, G.; Fiocco, D. Immunobiosis and probiosis: Antimicrobial activity of lactic acid bacteria with a focus on their antiviral and antifungal properties. Appl. Microbiol. Biotechnol. 2018, 102, 9949-9958. [CrossRef] 